\title{
Assessment of Pre-Competitive Research and Development Needs for Industrial Waste Minimization
}

\author{
J. K. Young \\ R. K. Sen \\ L. L. Fassbender
}

February 1992

Prepared for the U.S. Department of Energy under Contract DE-AC06-76RLO 1830

Pacific Northwest Laboratory

Operated for the U.S. Departiment of Energy by Battelle Memorial Institute 


\title{
DISCLAIMER
}

This repont was prepaned as an account of wonk sponsoned by an agency of the United States Government. Neither the United States Govermment mor any agency, thereof, nor Battelle Mernoriali institute, nor any of their employees, makes any warranty, expressed or implied, or assumes any legal liability or responsibility for the accuracy, completeness, or usefulness of any irformation, apparatus, product, or process disclosed, or represents that its use would not infringe privately owned rights. Reference therein to any specific commercial pnoduct, pnocess, on service by trade mame, tnademank, manufacturen, or otherwise does not necessarilly constitute or imply its endonsement, necommendation; or favoning by the United States Covernment on any agency theneof, or Battelle Mtemonial Imstitute. The views and opinions of authors expressed henein do not necessi.:ily stare or reflect those of the United States Govermment or any agency thereof.

\author{
PACIFIC NORTHHWEST LABORATORY \\ operated by \\ BATTELLE MEMORIALL INSTITUTE \\ for the \\ UNITED STATES DEPARTMENT OF ENERGY \\ under Contract DE-ACO6-76RLO 1830
}

Printed in the United States of America

Available to MOE and DOE contractory from the

Office of Scientific and Technical Information, P.O. Box 62, Oak Ridge, TN 37831; prices available from (615) $576-8401$. FTS $626-8401$.

Available to the public from the National Technical Information Service, U.S. Department of Commerce, 5285 Port Royal Rd., Springfield, V'A 22161. 
ASSESSMENT OF PRE-COMPETITIVE RESEARCH AND DEVELOPMENT NEEES FOR INDUSTRIALL WASTE MINIMIZATION

J. K. Young

R. K. Sen ${ }^{(a)}$

L. L. Fassbender

February 1992

Prepared for the U.S. Department of Energy under Contract DE-ACO6-76RLO 1830

Pacific Northwest Laboratory

Richland, Washington 99352

(a) R. K. Sen \& Associates Washington, D.C. 20016 


\section{ABSTRACT}

This report summarizes the findings of the first phase of a study undertaken to define a role for the Advanced Industrial Concepts (AIC) Division of the Office of Industrial Technologies (OIT) in developing waste minimization technologies for the industrial sector. The report describes the results of an industriat waste characterization based mainiy on the U.S. Environmental Protection Agency's (EPA's) 1989 Toxics Release Inventory (TRI) database. In addition, it contains the results of interviews with personnel from trade associations, environmental advocacy groups, federal agencies, and industrial firms regarding pre-competitive research and development needs for industrial waste minimization. Recommendations for future AIC waste minimization activities are provided. 


\section{EXECUTIVE SUMMARY}

This report summarizes the findings of the first phase of a study undertaken to define a role for the Advanced Industrial Concepts (AIC) Division of the Office of Industrial Technologies (OIT) in developing waste minimization technologies for the industrial sector.

The U.S. Environmental Protection Agency's (EPA's) 1989 Toxics Release Inventory (TRI) database was used to characterize industrial wastes. Despite many criticisms regarding potential underestimating, this database is stil1 the most comprehensive listing of industrial waste generators. The data were categorized based on the two-digit Standard Industrial Classification (SIC) codes of the industrial sectors that generated the wastes. As expected, the Chemicals and ATlied Products (SIC 28) sector clearly emerges as the top generator, with 49 weight percent iwt\%) of the total. Fabricated Metal Products (SIC 3.4); Machinery Except Elecirical (SIC 35); Electrical Machinery (SIC 36); Professional, Scientific, and Controlling Instruments (SIC 38); and MisC. Manufacturing (SIC 39) collectively generate another 10 wt\% of TRI releases. Other key generators include Paper (SIC 26) (6 wt\%), Primary Metals (SIC 33) (14 wt\%), Transportation (SIC 37) (4wt\%), PTastiCS (SIC 30) (4wt\%), and Petroleum (SIC 30) (2 wt\%). The total amount of TRI waste generated was 5.7 mitition pounds.

The analysis was extended to the four-digit SIC codes to obtain a more detailed picture of waste generators. The data showed that SIC 2869 (Industrial Organic Chemicals Not Elsewhere Classified) was the largest producer of waste within SIC 28. Within their respective two-digit SICS, SIC 2611 (Pulp Mills), SIC 2911 (Petroleum Refining), SIC 3079 (misc. Plastic Products), SIC 3312 (BTast Furnaces), and SIC 3711 (Motor Vehicle and Car Bodies) are the top generators. The commonality among the industrial categories mentioned above is that they are either producers or heavy users of hazardous chemicals. Thus, we decided to focus on waste minimization R\&D 
opportunities in industries that are either major producers or users of chemicals. This approach is consistent with the strategy taken by the office of Waste Reduction (OWR).

Interviews were scheduled with relevant federal officials at EPA and the Office of Technology Assessment (OTA) to obtain information on their current waste minimization programs and their future plans. Both EPA and OTA are strong believers in the concept of pollution prevention. Most of the EPA programs are very near-term in nature and focused on encouraging industry to implement waste minimization. Very little emphasis is on research that could lead to significant waste reduction in the ionger term. EPA program managers recognize the need for a parallel effort to pursue a long-term waste minimization R\&D program and are supportive of DOE taking the lead to initiate such a collaborative program with industry.

The industrial trade associations and the industries we interviewed concur with the opinions expressed by the EPA program managers. Clearly, industry's environmental efforts are predominantly directed toward "end-ofpipe" treatment, and that is where most of their R\&D dollars are being targeted. However, waste minimization is gaining increasing attention because uf its cost-effectiveness and its public relations advantages. The chemical Manufacturers Association (CMA) is implementing its "Responsible Care Program," and many examples abound of chemical industry leaders setting goals of reducing emissions by as much as $90 \%$. These goals are being met through available technologies, essentially by communicating a strong corporate commitment to waste reduction and rewarding employees who implement costeffective solutions. Although such an effort is clearly necessary, the leaders in industry are also fully cognizant of the continued need for research to develop next-generation technologies to continue the process of waste minimization.

The consensus of all the interviewees was that a federal role in such a research program is essential. However, they were quite careful in defining that role. The federal government should not develop technologies that are specific to a particular industry, even if the impact on pollution prevention is significant. Rather, it should carefully craft a set of applied research 
programs that are generic in nature. The results of this applied program could then be utilized by a broad range of industries to develop pollution prevention strategies relevant for specific plants and processes.

The environmental community promoting waste minimization is also supportive of a federal role in the program. In their opinion, government involvement would provide a stronger impetus to develop and implement waste minimization technologies. Such a program, they feel, should be closely coordinated with state and local authorities, who currently seem to have taken the initiative to promote pollution prevention concepts.

DOE is in a unique position to fill this role. It is a significant producer of wastes in its own facilities, and has recently initiated a massive program to deal with existing wastes and to modernize its plants to improve efficiency and reduce waste generation. In addition, through its office of Conservation and Renewable Energy, DOE is focusing on technology development programs that will improve energy efficiency and reduce unwanted by-products. These programs can clearly contribute much to waste reduction. The OIT is undertaking such an effort for the industrial sector through its OWR. The AIC Division can support the OWR activity by implementing a program to develop the long-term technology base for industrial waste minimization. This collaborative R\&D program with industry would conduct pre-competitive applied waste minimization R\&D in accordance with AIC's mission and capabilities.

This study also attempted to identify major generic research issues that would be beneficial to waste minimization technology development programs.

The general areas that emerge include:

- The development of process tecnnology to replace potentially toxic chemicals such as halogens in the pulp and paper industry and in other industrial processes using solvents.

- The development of corrosion-resistant, biodegradable, and more durable materials. These materials should use environmentally benign raw materials in the manufacturing process, and their disposal or recycling potential must be environmentally sound.

- The recovery of dilute contaminants in high-volume waste streams, which is critical to many recycling and waste remediation processes. Innovative separations technologies are essential to achieve this cost-effectively. 
- The implementation of sensors and process control technologies to improve efficiency and reduce waste generation.

- The development of technologies to recover value-added products from industrial wastes and used products. Technology to recover mixed plastics, process sludges, waste acids, spent catalysts, and metal-bearing waste streams are important research areas.

- The implementation of more selective process technology that reduces wastes by reducing 1) raw material inputs, 2) energy inputs, and 3) waste generation. This selectivity can be gained through the use of more selective catalysts or through the use of process design tools for optimizing process conditions.

These research issues are not prioritized, and it is understood that AIC may not be able to conduct research in all of them. The proposed research areas must be further evaluated in terms of suitability and their fit with $A I C^{\prime}$ s capabilities. In order to do so, we recommend the following in the second phase of this study:

- Quantify potential impacts on energy use and waste reduction as a result of a successful research program in the above mentioned areas. In addition, assess the impact they may have on the competitiveness of U.S. industry.

- Arrange a series of workshops with industry experts to evaluate the research areas and develop a prioritized list of specific research programs.

- Evaluate ongoing federal and industrial programs and develop a set of complementary R\&D programs for consideration by AIC within existing program areas or for a new waste minimization program complementary to OWR. 


\section{LIST OF ACRONYMS}

AIC Advanced Industrial Concepts

API American Petroleum Institute

AWMA Air and Waste Management Association

CEQ Council on Environmental Quality

CMA Chemical Manufacturers Association

CSWS Council for Solid Waste Solutions

DoD U.S. Department of Defense

DOE U.S. Department of Energy

EPA U.S. Environmental Protection Agency

HWDMS Hazardous Waste Data Management System

NES National Enërgy Strategy

NPRA National Petroleum Refiners Association

OBT Office of Building Technologies

OIT Office of Industrial Technologies

DTA Office of Technology Assessment

OWR Office of Waste Reduction

PERF Petroleum Environmental Research Forum

PIRG Public Interest Research Group

PNL Pacific Northwest Laboratory

POTW publicly owned treatment works

PVC poly-vinyl chloride

RCRA Resource Conservation and Recovery Act

$R \& D$ research and development

SARA 1986 Superfund Amendments and Reauthorization Act 


SIC Standard Industrial Classification
TRI Toxics Release Inventory
TSD treatment, storage, and disposal
VOC volatile organic compound
WPCF Water Pollution Control Federation
wt\%




\section{CONTENTS}

ABSTRACT .....................................

EXECUTIVE SUMMARY .......................... . . . . v

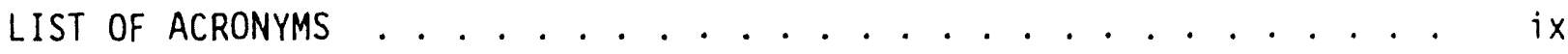

1.0 INTRODUCTION . . . . . . . . . . . . . . . . . . . . . . 1.1

1.1 MISSION OF THE ADVANCED INDUSTRIAL CONCEPTS DIVISION . . . . 1.3

1.2 SCOPE OF THE STUDY . . . . . . . . . . . . . . . . 1.4

1.3 APPROACH ..................... . . 1.5

1.4 WASTE MINIMIZATION: A DEFINITION . . . . . . . . . . . . 1.7

2.0 INDUSTRIAL WASTE CHARACTERIZATION . . . . . . . . . . . . . 2.1

2.1 CHARACTERIZATION BY INDUSTRIAL SECTORS . . . . . . . . . 2.2

2.2 MEDIA-SPECIFIC CHARACTERIZATION . . . . . . . . . . . 2.7

2.2.1 Air Emissions . . . . . . . . . . . . . . . 2.7

2.2.2 Water Emissions . . . . . . . . . . . . . . . 2.9

2.2.3 Land Disposal . . . . . . . . . . . . . . 2.10

2.3 CONCLUSIONS ....................... 2.11

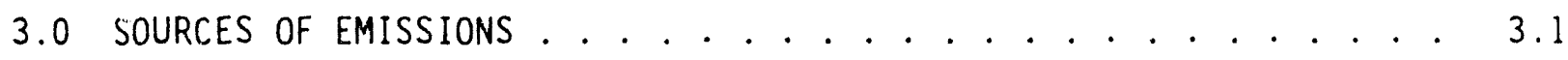

3.1 CHEMICALS INDUSTRY .................... . . 3.1

3.2 PAPER AND ALLIED PRODUCTS . . . . . . . . . . . . . . . . . 3.4

3.3 PETROLEUM PRODUCTS . . . . . . . . . . . . . . . . . . 3.4

3.4 PLASTICS . . . . . . . . . . . . . . . . . . . . 3.5

3.5 PRIMARY METALS . . . . . . . . . . . . . . . . . . . . 3.5

3.6 TRANSPORTATION EQUIPMENT . . . . . . . . . . . . . . . . . . 3.6

3.7 ELECTRONICS AND METAL FINISHING . . . . . . . . . . . . . . . 3.6

3.8 CONCLUSIONS . . . . . . . . . . . . . . . . . . . . . . 3.7 
4.0 RESEARCH AND DEVELOPMENT NEEDS ASSESSMENT:

THE INTERVIEW RESULTS . . . . . . . . . . . . . . . . . . . . 4.1

4.1 FEDERAL ENTITIES ..................... 4.1

4.2 THE ENVIRONMENTAL COMMUNITY . . . . . . . . . . . . . . . . 4.4

4.3 TRADE ASSOCIATIONS . . . . . . . . . . . . . . . 4.6

4.4 INDUSTRIAL INTERVIEWS . . . . . . . . . . . . . . . . 4.10

5.0 TOPICAL ASSESSMENTS . . . . . . . . . . . . . . . . . . . . 5.1

5.1 THE NATIONAL ENERGY STRATEGY . . . . . . . . . . . . . . . . 5.1

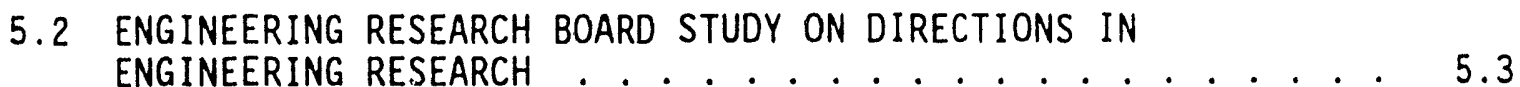

5.3 NATIONAL RESEARCH COUNCIL STUDIES . . . . . . . . . . . 5.3

6.0 CONCLUSIONS AND RECOMMENDATIONS . . . . . . . . . . . . . . 6.1

6.1 ANALYTICAL TOOLS ................... . . 6.2

6.2 PROCESS MODIFICATIONS ................ 6.3

6.3 NEW MATERIALS . . . . . . . . . . . . . . . . . . 6.3

6.4 PRODUCT SUBSTITUTION . . . . . . . . . . . . . . . . . . . 6.4

6.5 RESOURCE RECOVERY .................... 6.4

6.6 MONITORING SYSTEMS . . . . . . . . . . . . . . . . . 6.5

6.7 SEPARATIONS....................... . . 6.5

6.8 PHASE 2 OF THIS STUDY . . . . . . . . . . . . . . . . . 6.6

7.0 REFERENCES ............................ 7.1

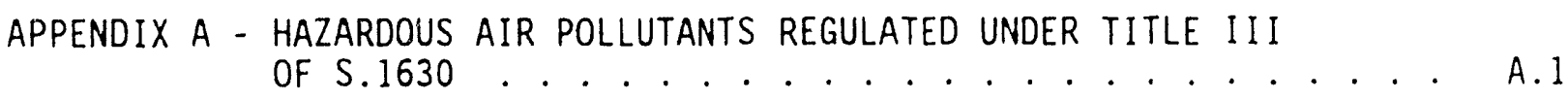

APPENDIX B - TOP 5 TRI EMISSIONS FROM TOP GENERATING 4-DIGIT SICS . . . B.1

APPENDIX C - INTERVIEWS . . . . . . . . . . . . . . . . . . . C.I 


\section{FIGURES}

1.1 Wasto Minimization Hierarchy................. 1.2

2.11989 Chemrical Releases and Transfers by 2-Digit SIC . . . . . . 2.2

2.2 Toxtic Release Inventory ............... 2.8

2.3 Contribution of Five Largest. Component. Types to Total Fugitive Emissions from Ethylene Oxide Production Facilitites Using Ethylene Fugitive Emisstions . . . . . . . . . 2.10

\section{TABLES}

2.1 The 25 Chemicals with the Largest 1989 TRI Releases . . . . . . . 2.4

2.2 Leading 4-Digit Generators Within 2-Digit Sics........ . 2.5

2.3 1980 Percentage of RCRA Hazardous Wastes Generated by Industry . . 2.6

2.4 Pollution Abatement Expenditures and Operating Costs, 1985 . . . 2.7 


\subsection{INTTRODLCTION}

Since its inception, the U.S. Envirommental Protection Agency's (EPA.'s.) regullatory phillosophy has been to improve environmental quility through mediaspecif pollution controll programs and regullations. These regullations. specif technology-based sttandards for waste treatment, discharge limitis, and proper disposal techniques. In response to this regullatory approach, an "endof-pipe" environmentall controll strategy evolved, focusing on treating a polliutant after it was generated rather than preventing its generation. Such $a$ strategy was necessary to begin the process of environmenta? restoration, and to a certain extent, it has been successfull. However, despite its success, an awareness emerged that the end-of-pipe control measures were simply shifiting: pollution from one medium to another, and, in addition, were imposing a heavy cost burden on U.S. industry. The rieed for a new strategy to deal with environmental pollution became apparent, and in the mid-1980s: waste minimization emerged as the strategy.

Passage of the Hazardous and Sollid Waste Amendments of 1984 to the Resource Conservation and Recovery Act. (RCRA) marked the beginning of the mew: EPA strategy. For the first time, waste generators were requiurad to describe their efforts to mininize waste generation and the results that were actulally achieved. EPA's approach to impilementing this strategy was first documented in a 1986 Report to Congress called Minimization of Hazardous Waste (EPA 1986) and reinforced in their 1988 Science Advisory Board report, Future Risk: Research Strategies for the 1990s (EPA 1988). EPA's new approach stressed source reduction and waste recycling as additional: key components to its a)ready significant effort in waste treatment and disposaT. The waste minimization hierarchy recommended by EPA is i7lustrated in Figure 1.1. The underlying principie is that the top options in the hierarchy provide more protection to the environment than the lower-level options. Source reduction emerges as the strong favorite over a 17 other options because a 171 other wastehandiing scenarios ultimately result in some type of emissions and basically transfer pollution from one medium to another (Wolf 1988). 
Source Reduction. The reduction or elimination of waste at the source. Source reduction measures include product and process modifications, feedstock substitution, improvements in feedstock purity, housekeeping and management practice changes, increases in the efficiency of equipment, and recycling within a process.

Recycling. The use or reuse of waste as an effective subistitute for a commercial product or as an ingredient or feedistock in an industrial process. It includes the reclamation of useful constituent fractions within a waste material or the removal of contaminiants from a waste to al low it to be reused.

Treatment. Any method, technique, or process that changes the physical, chemica 7 , or biological character of any waste so as to neutralize it, recover energy or material resources from it, or render it non-hazardous, less hazardous, safer to manage, amenable for rec sery, amenable for storage, or reduced in volume.

Disposa1. The discharge, deposit, injection, dumping, spilling, leaking, or placing of waste into or on any land, water, or atir.

\section{FIGURE 1.1. Waste Minimization Hierarchy}

To implement the hierarchy, EPA launched the Waste Minimization Research Program in 1987, which focused on preventing or reducing the generation of waste. Subsequentiy, the term "waste minimization" (which was thought to apply to source reduction and recycling activities under RCRA) was expanded to include all wastes, and it is now sometimes referred to as "politution prevention." The poltution prevention strategy seeks to limit the use of treatment and disposal options for waste and strongly encourages reduction of waste either at the source or through recycling. (EPA 1990). In 1988 EPA created an agency-wide Poliution Prevention Office to promote an integrated, multi-media poliution prevention program focused primarily on source reduction. The goat 
for this office is to educate the public, government, and industry on the need to initiate multi-media polliution prevention programs.

Recentily, the U.S. Department of Energy (DOE) has begum to address the major environmental issues at its production facilities. In additition, the Assistant Secretary for Conservation and Renewable Energy has directed that DOE's sigmificicanti research and development ( $R$ \& $Q$ ) efforts to develop energy efficiency and renewable emergy technollogies shoulid allso include waste mimimization as a key component. DOE's Office of Industrial Technollogies. (OIT) has undertaken a major initiative through its Office of Waste Reduction (OWR') to implement a coordinated technology development program with the objective of improving energy efficiency and reducing waste generation in the industriat sector. The Advanced Industrial Concepts (AIC) Division of OIT intends to support this major activity.

To establish a wel1-founded role, AlC requested that Pacific Nortthwest Laboratory (PNL) undertake a study to define those needs in waste mimimization research that would be consistent with AIC's mission and capabilitities and supportive of the OWR initiative. This report providies a summary of thie first phase of the AlC study and recommends a course of action for the second phase.

\subsection{MISSION OF THE ADVANCED INDUSTRIAL CONCEPTS DIVISION}

The AIC Division is part of DOE'S OIT. It.s primary mission is to develop a technology base for energy-efficient technologies for the manufacturing industries and to support the technology development programs of the other divisions of OIT through collaborative pre-competitive research programs with industry. AIC's project selection criteria emphasize working with U.S. industry to assist them in maintaining and/or improving their competitive position in the global marketplace. To meet these objectives, AIC generaliy funds programs that have strong industrial support and participation.

The current work elements of the AIC program include combustion, catalysis/biocatalysis, materials, and thermal sciences. AIC has developed strong capabilities in these work elements as well as a good working relationship with many industrial sectors, including the chemicals industry and the automotive industry. AIC expects to utilize its capabilities and its 
knowledge of some significant industries in undertaking a program to eninance the waste minimization technology base and support the Industrial waste Reduction Program undertaken by the OWR.

The AIC role in waste minimization will meet the following criteria:

- It must support AIC's mission and goals.

- It must be based on AlC's existing capabilities.

- It must be fully complementary to the activities supported by other DOE offices, particularly the efforts of OIT'S OWR, as we 17 as. EPA and U.S. Department of Defanse (DOD) activities.

- It must have the support of industry and environmental advocacy groups.

To meet these criteria, this study focused on identifying those precompetitive R\&D opportunities in waste minimization that AIC can support with fult industrial participation. An additional goal was to secure the support of the environmentai community in this program.

Recently there has been a greater emphasis on reducing the generation of waste as opposed to treating it after it has been generated. This new approach is increasingly being recognized as providing the most cost-effective solution to maintaining environmental quality. The approach is described by a host of names, including waste reduction, waste minimization, pollution prevention, and source reduction. The differences in the programs proposed under these various names have to do with the type of processes used to reduce the generation of waste. For the purposes of this study, we have defined waste minimization to include approaches that will reduce the production of waste at the source through: 1) process modifications, 2) product substitutions, and 3 ) recycling and reuse.

\subsection{SCOPE OF THE STUDY}

The objective of this study is to assess the need for pre-competitive applied research in waste mininization technologies that would support. AIC's mission and goals. The study is also expected to recommend specific research 
topics that, if successful, will have the maximum impact on both waste minimization and energy efficiency. Specifically, the study addresses

- the need for an R\&D program to develop a technology base for improving both energy efficiency and waste minimization for the industriat manufacturing sector

- the potential positive impact of such a program on the competitivemess of U.S. industry

- the witlingness of industry to participate in, support, and guide the management of such a collaborative program

- the relationship of the proposed R\&D effort to ongoing waste minimization activities at other federal agencies, particularly at EPA, DoD, and other DOE offices. The emphasis is to propose research areas that would be complementary to and supportive of these existing and pianned programs

\subsection{APPROACH}

In conducting this study, we involved interested parties from industry, government, and the environmental community as early as possible. The approach we have taken to accomplish the study objectives includes

- reviews of available literature and databases to characterize industrial waste generation. This task also identifies the key industrial generators and the corresponding unit operations or processes generating most of the waste.

- interviews with industrial trade associations and industrial decision makers to understand key industrial needs and concerns. These interviews also served as the basis for exploring mechanisms for AIC/industry collaboration in waste minimization research.

- interviews with environmental advocacy groups to understand emerging public perceptions regarding pollution prevention and to develop bridges that could bring about effective support from the environmental community for $D O E^{\prime} s$ waste minimization research efforts

- interviews with EPA program managers to understand the agency's position on pollution prevention and the role it intends to play in promoting pollution prevention R\&D. 
The strategy behind this approach was that the recommended role for AIC and the long-term generic R\&D needs in waste minimization should occur through an interactive process.

Waste minimization efforts must eventualiy encompass all industrial sectors. A research program to advance the technology base in waste minimization can potentially be very broad. Unfortunately, it is highly unlikely that AIC can undertake such an all-encompassing research agenda with its 7 imited resources. Rather, it must confine itself to where its capabilities can be effectively used to have the maximum long-term benefits. Thus, the first task of this study is to use existing databases and public literature to undertake a thorough characterization of wastes generated by the industrial sector. This task also attempts to delineate current efforts in waste minimization by the various industrial sectors. The definition of this industrial waste generation envelope is essential to identify the highest-priority industrial sectors, where the need for waste minimization is high and where a targeted AIC-supported program can have maximum impacts.

After completing the waste characterization task, interviews were arranged with federal agencies, industrial trade associations, industrial decision makers, and the environmental community to

- validate the priorities established through the waste characterization task

- discuss and define the role AIC can play in waste minimization research based on its mission and capabilities

- assess current waste minimization activities in the federal government and in industry to define a role for AIC that is complementary to existing and planned efforts.

- define pre-competitive R\&D needs in waste minimization for the targeted industrial sectors.

A broad spectrum of views was solicited through the interviews. In addition to helping define the R\&D needs, these interviews signify the first step in building a long-term relationship with the key players in 
environmental decision-making, who often have very divergent objectives. A good working relationship with this core group is essential if the planned AIC program is to be successful.

The tasks described so far form the basis of phase 1 of this study, the results of which are presented in this report. In phase 2 , we anticipate arranging a series of workshops to discuss and review the findings of the first phase in order to refine a prioritized 1ist of R\&D issues that AIC can address in a detailed waste minimization program plan.

\subsection{WASTE MINIMIZATION: A DEFINITION}

The concept of reducing the amount of waste generated as a sound environmental strategy is promoted through many programs with names such as "Pollution Prevention," "Waste Reduction," "Source Reduction," and "Waste Minimization." While many similarities exist in these programs, there are also significant differences. Thus, for the purpose of clarity, it is necessary to define "waste minimization" as it is used in this study. Essentially, we intend to follow the guidelines suggested in EPA's 1990 Pollution Prevention Research PIan - Report to Congress (EPA. 1990), where the type of research activities considered under waste minimization are as follows:

- Product Research: This includes developing new products to replace existing products that are environmentally undesirable.

- Process Research: This includes developing modifications to existing pracesses that minimize the production of unwanted by-products.

- Recycle and Reuse Research: This includes developing costeffective recycling technologies for materials used in our industrial society, thus reducing the amount of waste generated. An additional benefit is that such research promotes resource conservation.

We have deliberateiy excluded waste treatment and incineration from our consideration because the treatment of waste (either to reduce its volume or to convert a hazardous waste to a non-hazardous form for disposal) does not constitute waste minimization. For example, incineration is a technology that converts solid or liquid waste into a gaseous form and reall! does not satisfy the criteria of waste minimization. 


\subsection{INDUSTRIAL WASTE CHARACTERIZATION}

Most of the data used to characterize industrial waste are generated by EPA with information received from industry. This information is required from industry through many of the mandated reporting requirements of environmental legislation. Wastes are generally classified as hazardous, nonhazardous, and toxic. These classifications have emerged in response to a variety of environmental regulations that have evolved over the years. Unfortunately, the definitions employed in the various regulations are not always consistent and can sometimes lead to classification of a particular waste in more than one category. Industrial reporting is also not consistent, which raises serious questions about the extent of underestimating that occurs in the EPA databases.

Nevertheless, the 1989 Toxics Release Inventory. (TRI) database remains the most exhaustive description of industrial waste generation. The 1986 Superfund Amendments and Reauthorization Act (SARA) created the TRI database on industrial releases of toxic chemicals. The key section is Title lll of SARA, Section 313 of the Emergency Planning and Community Right to know Act, which requires facilities in Standard Industrial Classifications (SICS) 20 to 39 to file data on the use of over 300 chemicals. We have used this database in our analysis and supplemented it with existing analyses of industrial waste available in the RCRA hazardous waste database and the published literature. In addition, we have relied on the analysis performed by the OWR in their Industrial Waste Reduction Program Plan. (a) The TRI database was especially useful for characterizing industrial emissions at the 4-digit SIC level. Such a characterization is necessary to identify the processes and unit operations that represent the greatest opportunities for waste minimization.

(a) Industrial Waste Reduction Program - Program Plan (Internal Draft). October 24, 1991, Office of Industrial Technologies, U.S. Department of Energy. 


\subsection{CHARACTERIZATION BY INDUSTRIAL SECTORS}

The 1989 TRI distribution of toxic waste generation as a function of two-digit SIC codes is shown in Figure 2.1. At this macro-level, the chemicals industry contributes most to the U.S. environmental problems and should be the larget of major waste reduction efforts. The other significant contributors are the primary metals, transportation, plastics, petroleum, and the pulp and paper industry.

Industries differ considerably in the chemical composition of their TRI releases and transfers. (a) Based on 1988 TRI data, the chemicals industry is responsible for $42 \mathrm{wt} \%$ of all organic releases; $70 \mathrm{wt} \%$ of all releases of acids, bases, and salts; and $20 \mathrm{wt} \%$ of the releases of halo-organics. The

$\begin{array}{ll}\text { SIC } 26 \text { Paper } & \text { SIC } 34 \text { Fab. Metals } \\ \text { SIC } 28 \text { Chemicals } & \text { SIC } 35 \text { Machinery } \\ \text { SIC } 29 \text { Petroleum } & \text { SIC } 36 \text { Electrical } \\ \text { SIC } 30 \text { Plastics } & \text { SIC } 37 \text { Transportation } \\ \text { SIC } 33 \text { Primary Metals } & \text { SIC } 38 \text { Measure/Photo. }\end{array}$

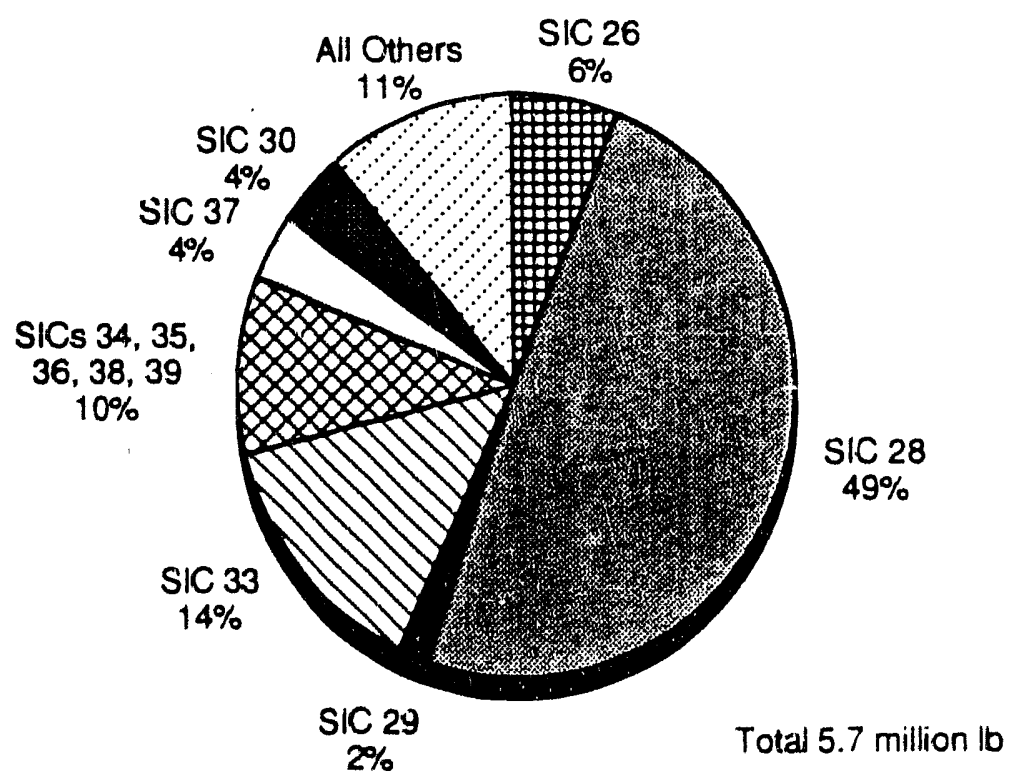

FIGURE 2.1. 1989 Chemical Releases and Transfers by 2-Digit SIC

(a) A TRI release is an emission to air, water, and/or land as reported by the Toxic Release Inventory. 
remainirg $80 \mathrm{wt} \%$ of the halo-organic releases were fairly evenly distributed between several industrial sectors, which basically represent the users of halo-organic solvents and degreasers. The pulp and paper industry contributed $10 \mathrm{wt} \%$ of all the organic releases. As would be expected, the primary metals industry released the largest amount of metals and metal compounds (64 wt\%).

The 25 chemicals with the largest releases are shown in Table 2.1; they represent 83 wt\% of total TRI releases. Ammonium sulfate, hydrochloric acid, methanol, sulfuric acid, ammonia, toluene, and acetone accounted for $52 \mathrm{wt} \%$ of the TRI releases and transfers. The chemicals industry is the major source of these chemicals. The primary metals industry is the leading source of zinc, zinc compounds, copper compounds, and chlorine. Releases of toluene, $1,1,1$ trichloroethane, trichloroethylene, methyl ethyl ketone (MEK), xylene, and freon 113 are distributed over several industries. Although not shown in the table, the fabricated metals industry uses a substantial amount of trichloroethylene, glycol ethers, and n-butyl alcohol, and thus ends up being a significant contributor to their release to the environment.

Industrial patterns of waste generation at the four-digit SIC level for the top 25 SIC codes are shown in Table 2.2. The leading generators within the chemicals industry are Industrial Organic Chemicals, not elsewhere classified (SIC 2869), Inorganic Pigments (SIC 2816), Nitrogenous Fertilizers (SIC 2873), Industrial Inorganic Chemicals, not elsewhere classified (SIC 2819), and Plastic Materials and Resins (SIC 2821). Other leading generators within their respective 2 -digit SIC codes are Pulp Mills (SIC 2611), Petroleum Refining (SIC 2911), Blast Furnaces (SIC 3312), Primary Nonferrous Metals, not elsewhere classified (SIC 3339), and Motor Vehicles and Car Bodies (SIC 3711).

Another source of information on industrial sources of waste is the RCRA Hazardous Waste Data Management System (HWDMS). This database was developed from data in RCRA permit applications. The HWDMS contains data on approximately 4,500 treatment, storage, and disposal (TSDs) facilities; 18,000 
TABLE 2.1. The 25 Chemicals, with the Largest 1989 TRI Releases (wt \% of Total)

\begin{tabular}{|c|c|c|}
\hline Chemical Name & Percent & Largest Generator \\
\hline Ammonium Sulfate (solution) & 13 & Chemicals \\
\hline Hydrochloric Acid & 9 & Chemicals \\
\hline Methanol & 7 & Chemicals \\
\hline Ammonia & 7 & Chemicals \\
\hline Toluene & 6 & Chemicals \\
\hline Sulfuric Acid & 6 & Chemicals \\
\hline Acetone & 4 & Chemicals \\
\hline$x y^{\prime}$ lene (mixed isomer) & 3 & Transportation \\
\hline $1,1,1$ Trichloroethane & 3 & Transportation \\
\hline Zinc Compounds & 3 & Primary Metals \\
\hline : & 3 & Plastics \\
\hline Chlorine & 2 & Primary Metals \\
\hline Dichloromethane & 2 & Chemicals \\
\hline Manganese Compounds & 2 & Primary Metals \\
\hline Carbon Lisulfide & 2 & Chemicals \\
\hline Phosphoric Acid & 2 & Chemicals \\
\hline Nitric Acid & 1 & Chemicals \\
\hline Ammonium Nitrate & 1 & Chemicals \\
\hline Freon 113 & 1 & Electrical \\
\hline Glycol Ethers & 1 & Fabricated Metals \\
\hline Zinc (Fume or Dust) & 1 & Primary Metals \\
\hline Ethylene Glycol & 1 & Chemicals \\
\hline Copper Compounds & 1 & Primary Metals \\
\hline Chromium Compounds & 1 & Chemicals \\
\hline N-Butyl Alcohol & 1 & Chemicals \\
\hline Total & 83 & \\
\hline
\end{tabular}

(a) Toxic Release Inventory Aggregate Data. 1991. Obtained from the TRI User Support Service (202-382-3531). 
IABLE 2.2. Leading 4-Digit Generators Within 2-Digit SICs

SIC Code

SIC 28

2869

2819

2873

2821

2816

Total

SIC 26

2611

2621

2631

Total

SIC 29

2911

SIC 30

3079

SIC 33

3312

3339

3331

3341

Total

SIC 37

3711

3714

Total
SIC Code Name

Industrial Organic Chemicals, nec

Industrial Inorganic Chemicals, nec

Nitrogenous Fertilizers

Plastic Materials and Resins

Inorganic Pigments

Pulp Mills

Paper Mills

Paperboard Mills

Petroleum Refining

Misc. Plastic Products

Blast Furnaces

Primary Nonferrous Metals, nec

Primary Copper

Primary Smelting \& Refining of Copper

Motor Vehicles \& Car Bodies

Motor Vehicle Parts \& Accessories
98

24

Wt $\%$ of

2-digit SIC

$\begin{array}{r}27 \\ 14 \\ 8 \\ 7 \\ 7 \\ \hline 63\end{array}$

38

20

$\frac{13}{71}$

34

24

11

$\frac{9}{78}$

28

$\frac{22}{50}$

transporters; and approximately 210,000 large-and small-quantity generators. RCRA includes only solid waste; however, the statute's definition of "solid waste" is incredibly broad:

any garbage, refuse, sludge, from a waste treatment plant, water supply treatment plant, or air pollution control facility and other discarded material, including solid, liquid, semisolid, or contained gaseous material resulting from industrial, commercial, mining, and agricultural operations, and from community activities, but does not include solid or dissolved material in domestic sewage, or solid or dissolved materials in irrigation return flows or industrial discharges which are point sources subject to permits 
under section 402 of the Federal Water Pollution Control Act, as amended (86 Stat. 880), or source, special nuclear, or byproduct material as defined by the Atomic. Energy Act of 1954, as amended (68 Stat. 923).

Based on the HWDMS, EPA has categorized hazardous waste generators by volume of RCRA hazardous waste produced (Table 2.3). Statistics show that SIC codes $28,29,33,34,36$, and 37 generate the most hazardous waste and are, thus, most heavily burdened by waste treatment and disposal costs (EPA 1989). The top 50 generators of hazardous waste accounted for approximately $80 \%$ of the total RCRA tonnage. The following five RCRA waste codes accounted for $86 \%$ of the total hazardous wastes reported:

$\begin{array}{lr}\text { D002 (corrosive waste) } & 42.1 \mathrm{wt} \% \\ \text { MOMX (mixtures, general) } & 31.9 \mathrm{wt} \% \\ \text { DOMX (mixtures, characteristic) } & 6.2 \mathrm{wt} \% \\ \text { D002 (chromium waste) } & 3.3 \mathrm{wt} \% \\ \text { KOMX (1 isted industrial) } & 2.5 \mathrm{wt} \%\end{array}$

The Census Bureau provides estimates of pollution control costs for various industries (Table 2.4). Again the chemicals, primary metals, and pulp and paper industries emerge as having the maximum waste handling costs (U.S. Bureau of Census 1987).

TABLE 2.3. 1980 Percentage of RCRA Hazardous Wastes Generated by Industry (EPA 1989)

\begin{tabular}{|c|c|c|}
\hline SIC Code & Industry & Amount Generated (wt\%) \\
\hline 28 & Chemicals \& Allied Products & 62 \\
\hline 33 & Primary Metals & 10 \\
\hline 29 & Petroleum \& Coal Products & 5 \\
\hline 34 & Fabricated Metal Products & 5 \\
\hline 36 & Electric \& Electronic Equipment & 3 \\
\hline 37 & Transportation Equipment & 3 \\
\hline 26 & Paper \& Allied Products & 3 \\
\hline
\end{tabular}


TABLE 2.4. Poillution Abatement Expenditures and Operating Costs, 1985 (U.S. Bureau of Census 1987)

\begin{tabular}{l} 
S.IC Code \\
\hline 28 \\
29 \\
33 \\
26 \\
37 \\
20 \\
36 \\
34 \\
32 \\
35 \\
24
\end{tabular}

Industiry
Chemicalls \& Alllied Products
Petroileum
Primary Metalls
Paper
Transportiation Equipment
Food
Eleciricail Machinary
Fabricated Metalls
Stone, Clay, \& Gilass
Machinery, exc. Electrical
Lumber \& Wood

\begin{tabular}{c}
$\begin{array}{c}\text { Poillution Conitroil } \\
\text { Cos.ts }(\$ M)\end{array}$ \\
\hline $3,278.1$ \\
$2,353.8$ \\
$2,1115.9$ \\
$1,453.2$ \\
$1,195.3$ \\
987.2 \\
565.9 \\
525 \\
455.1 \\
412.6 \\
173.6
\end{tabular}

\subsection{MEDIA-SPECIFIC CHARACTERIZATIION}

It is important to analyze how the emissions are occurring (i.e., whether they are released to the air, water, or liand). Such media-specific probilems have been the traditional focus of much public concern. The environmental distribution of industrial sources of pollution is characterized in Figure 2.2. Actual quantities of wastes released to the environment are much higher than the values indicated by TRI because industry is just one source of environmental pollution; other sources include automobile exhaust, human activities, and catastrophic events. In addition, TRI data do not include pollution from agriculture, mining, or small-quantity industrial generators.

\subsubsection{Air Fmissions}

Air pollution can result in significant human exposures to toxic substances. While people drink 1 to 2 liters of water per day, they breathe 15,000 to 20,000 7iters of air per day (Citizens Fund 1990). UnTike water, controlling the purity of ingested air before consumption is extremely difficult. Typically, the concentration of chemical compounds is 


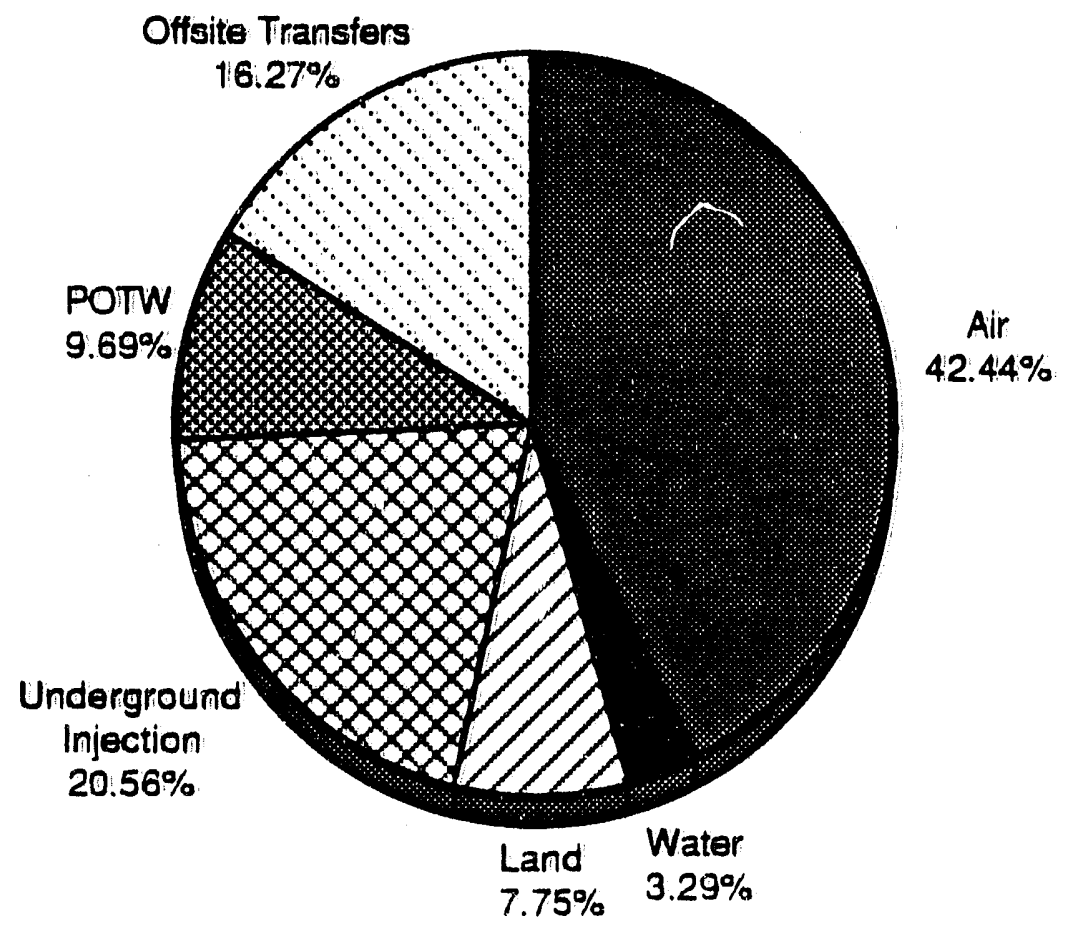

FIGURE 2.2. Toxic Release Inventory (1989 Releases and Transfers.)

significantly higher in urban air than in rurat air (Sanders 1986). In addition, toxic air pollutants settle and result in contamination to streams, lakes, and aquatic species.

Limited regulatory attention to air pollutants in the past has resulted in a serious lack of data on emissions of polTutants to the air. Under the original Clean Air Act, standards were set for only seven hazardous air pol7utants. However, many more were released into the environment. The new Clean Air Act mandates regulations on 189 chemicals (Appendix A). With its passage in 1990, much more detailed information on air emissions wit1 undoubtedly be collected and become available. But for now, the TRI database probably provides the most complete quantitative estimates of releases to the environment for most chemicals. 
Of the 5.7 millition pounds of TRI releases and iransfers in 1989, 43 wt\% were air emissions. Five industries accounted for 72 wt\% of tota 7 air emissions: chemicals ( 32 wto $)$, pulp and paper (11 wt\%), primary metals (113 wto ), transportation equipment $(9 \mathrm{wt} \%)$, and pilastics $(7 \mathrm{wt} \%)$. Of the total 1989 TR.I air emissions, 69 wt\% were released from point sources and 311 wt\% were fugitive emissions. Organics reportedly account for the largest portion of TRI air emiissions. One reason is that these chemicals evaporate easilly, especialliy when used in unsealled containers for purposes of cleaning or formulating other products. Halo-organics contributed the second largest amounit followed by non-metali inorganics.

According to 1987 TRI estimates, fugitive voliatile organic compound (VOC) emissions represent almost 20 wt\% of total air emissions. For the most. part, estimates of fugitive VOC emissions are calcullated based on industrywide emission factors developed by EPA for specific pieces of equipment. To. illustrate the contribution of various pieces of process equipment to totall fugitive VOC emissions, the results of actual measurements of fugitive voc emissions at an ethylene oxide facilitity are shown in Figure 2.3. Leaking: pumps and flanges accounted for most voc emissions, and over 70 wit $\%$ of toittal air emisstions measured in the study (Bergland et a.1. 1990).

\subsubsection{Water Emissions}

of the 5.7 milition pounds of TRI releases and transfers in 1989, approximately 21 wt\% was released to underground we $17 \mathrm{~s}, 10 \mathrm{wt} \%$ was discharged to public sewers (where the discharge may undergo treatment and destruction), and 3 wt\% was discharged to surface water. The TRI database indicates that the CinemicaTs (SIC 28) accounts for 87 wt\% of the total water discharges of toxic chemicals. Three other industries accounted for most of the remaining discharges: Petroleum (SIC 29), Primary Metals (SIC 33), and Paper (SIC 26) (EPA 1991).

Over half of the chemicals industry releases $(59 \mathrm{wt} \%$ ) were discharges to water. The chemicals industry accounted for $92 \mathrm{wt} \%$ of injection into underground wells. According to the 1988 TRI (EPA 1990), acids/bases/salts account. for the largest portion of TRI discharges to surface water ( $88 \%)$, public sewers ( $58 \mathrm{wt} \%$ ), and underground injection ( $86 \mathrm{wt} \%$ ). Organics represent. 


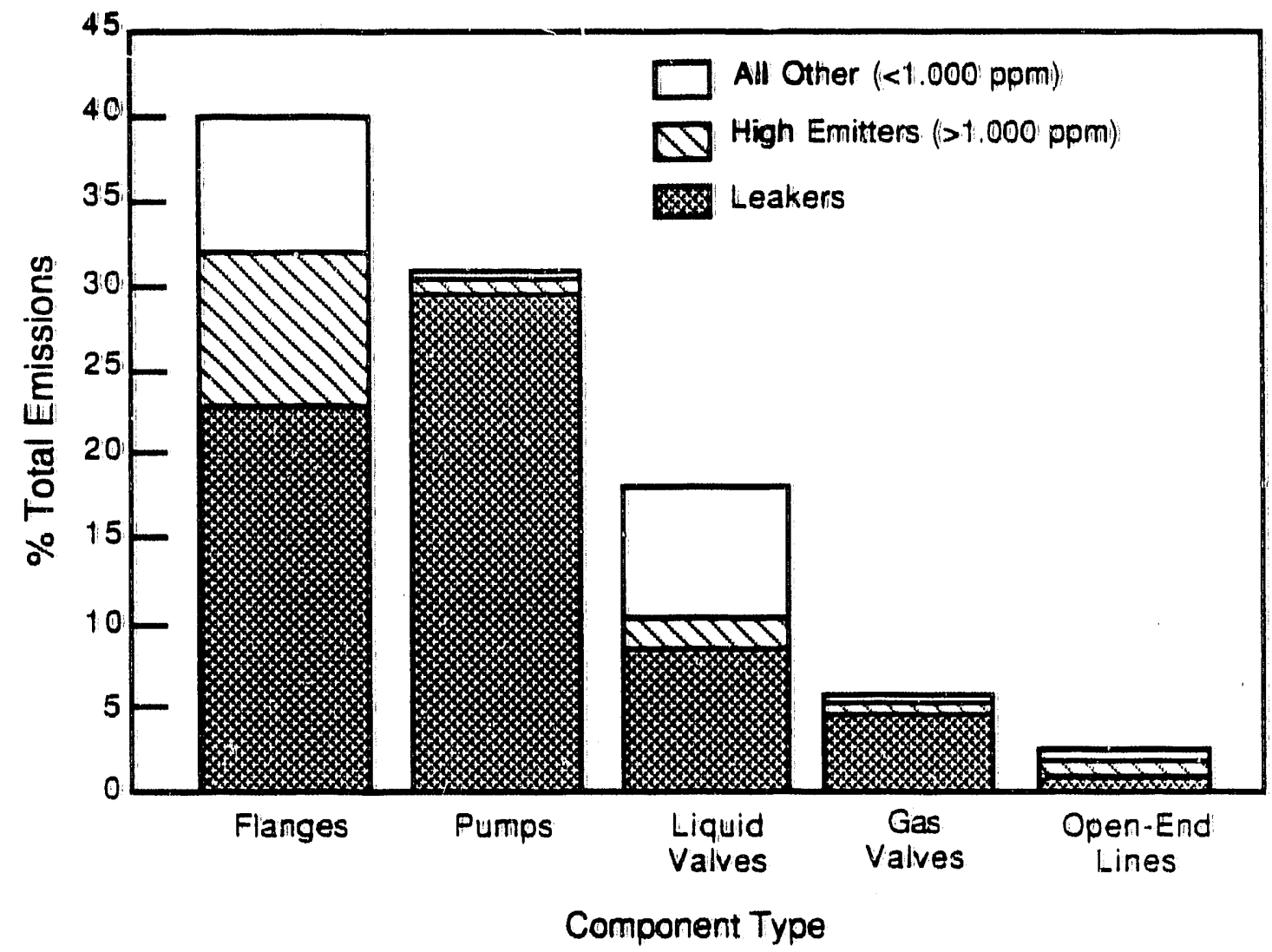

FIGURE 2.3. Contribution of Five Largest. Component Types to Total Fugitive Emissions from Ethylene Oxide Production Facilities Using Ethylene Fugitive Emissions (Bergland et al. 1990)

35 wt\% of the discharges to public sewers and 9 wt\% of the discharges to underground wells and surface waters.

\subsubsection{Land Disposal}

Offsite transfers represent 16 wt\% of TRI releases and transfers. Onsite land disposal represents another 8 wt\%. Two industries accounted for the majority of onsite land disposal nationwide: primary metals (66 wt\%) and chemicals $(28 \mathrm{wt} \%)$. These same industries dominated offsite transfers, with chemicals representing $40 \mathrm{wt} \%$ and primary metals accounting for $11 \mathrm{wt} \%$. Based on 1988 TRI data, metals represent over half of onsite land disposal. Offsite transfers are divided between metals, acids/bases/salts, and organics. 


\subsection{CONCLUSIONS}

Analysis of the TRI and HWDMS databases and other publicly availiable databases indicates that key industrial sectors where waste minimization could most dramatically impact energy use and environmental contamination include SIC 28 (Chemicalls and ATTied Products), SIC 26 (Paper and AT7 ied Products), SIC 29 (Petroleum and Coal Products), SIC 30 (P7astics), SIC 33 (Primary Metals), and SIC 3.7 (Transportation). Organics constitute the largest source of air emissions. Due to the large number of organics to be regulated in the new Clean Air Act, R\&D to minimize or eliminate both fugitive and point source air emissions could represent a key technology need. Longer-term efforts are also warranted to replace some of these hazardous chemicals from routine use. The Chemical Manufacturers Association (CMA) is already studying this problem.

Most industrial emissions to water result from releases of relatively innocuous acids/bases/salts. Some of them are being gradualiy de-listed and the others can be handled reliatively easily with current techmology. Toxic chemicals are also released, such as dioxin from pup milits and metal ions from primary metals industries. The absolute concentrations of these toxics are very low, monetheless they are hazardous. A likely focus for future efforts in water pollution control will be the cost-effective removal of these dilute contaminants from waste water, which would allow the water to be safely recycled. 


\subsection{SOURCES OF EMISSIONS}

It is difficult to determine what types of processes generate emissions given the limited information that is publicly available. However, we have attempted to gain some insights through: 1) analysis of the 1989 TRI database, 2) use of in-house data, and 3) a review of the current literature. TRI runs were completed to determine the leading 4-digit SIC generators (and associated chemical emissions) for the top-generating 2-digit SICs (see Figure 2.1). In-house data (Moore and Wilfert 1987), industry waste surveys, and EPA data are used to determine, whenever possible, the likely unit operation or process generating the wastes. This chapter summarizes our findings, which should be considered typical examples rather than a comprehensive listing of all the processes that produce industrial emissions.

\subsection{CHEMICALS INDUSTRY (SIC 28)}

SIC 28 produces 49 wt\% of the total TRI releases and transfers, of which at least 63 wt\% of the total is generated by the following 4 -digit SIC codes: Industrial Organic Chemicals, not elsewhere classified, nec (SIC 2869); Inorganic Pigments (SIC 2816); Nitrogenous Fertilizers (SIC 2873); Plastic Materials and Resins (SIC 2821); and Industrial Inorganic Chemicals, nec (SIC 2819). Top chemicals emitted by these 4-digit SICs are listed in Appendix B. The following sections describe the processes that generate many of the TRI releases and transfers within these 4 -digit SICS. The diversity of SIC 28 makes the identification of specific products and processes difficult and incomplete.

Waste Acids \& Salts. Acids are used as reagents in a number of important chemical reactions. They also serve as solvents, catalysts, and $\mathrm{pH}$ adjustment agents. Waste process acids can be recovered and reused, but many streams are eventually too dilute or contaminated with metals and organics for cost-effective recovery. Acids and bases are also added directly to waste water to precipitate metal ions and neutralize caustic or acidic waste streams. 
Fugitive Emissions. Fugitive emissions occur in Industriat Organic Chemicals, nec (SIC 2869) because VOCS such as methylene chloride, methanol, toluene, n-butyl alcohol, trichloroethylene (TCE), acetone, trichloroethane, ethylene glycol, and ethylene oxide (Bergland et al. 1990) are emitted from process equipment during their production. Principal sources of fugitive VOC emissions are from catalytic reactor vents; condenser vents; dryer vents; distillation column vents; and leaks in pipes, pumps, tanks, and valves (Dept. of Ecology 1990). Most vented emissions are treated before release, but technology to reduce the amount and handing of process chemicals would further reduce leaks and emissions from process equipment.

Chlorinaced Solvents Manufacture. Chlorine is released during nanufacture of Industrial Organic Chemicals, nec (SIC 2869). This is because many of the products of this SIC are chlorinated solvents. Minimizing chlorine emissions from the production and use of these chlorinated chemicals will uitimately require the development of non-chlorinated solvent substitutes. Many of the substitutes currently being developed are non-chlorinated vegetable oil derivatives, or orphan chemicals from the petrochemicals industry. Many of the chemical behaviors of available substitutes (e.g., vapor pressure, drying time) differ from conventional solvents; thus, substitution may require changes downstream in the processes and in practices currently employed by the users of these solvents.

Still Bottoms. Still bottoms are process residues created during the manufacture of Industrial Organic Chemicals (SIC 2869 and several other SICS) when chemical feedstocks are distilled to remove useful products or water. In addition, residual organics polymerize into sludge that settles to the bottom of tanks, reactors, and stills. This sludge must be treated as solid hazardous waste and shipped offsite for disposal or undergo a variety of treatment processes. According to industry representatives, technology is needed to convert these sometimes hazardous materials into value-added products for reuse.

Spent Catalysts. Many SICs within the chemicals industry (SIC 2869 and other SICS) use large quantities of metal catalysts that must be disposed of 
after their useful lives. According to industry representatives, the economics of regenerating spent catalysts are currently poor except for highvalue metals such as platinum. Cost-effective regeneration of catalysts and envirunmentally acceptable catalysts are needed.

Fertilizer Production. Ammonia is emitted from reactor vents and drying operations during production of Nitrogenous Fertilizers (SIC 2873) (DOE 1990a). In the reformer, ammonia may be volatilized due to incomplete reactions as well as due to the presence of excess free ammonia. Ammonia emissions are usually sent to a scrubber where ammonia is recovered as ammonium hydroxide, stored in scrubber tanks, and disposed of by putting it on farm fields to add nitrogen to the soil. Many companies do not feel that ammonia is a toxic gas; therefore, only limited efforts are aimed at developing improved control technology. Injecting ammonia emissions back into the reformer stack would be acceptable if technology were developed to reduce nitrogen oxide emissions.

Inorganic Pigment Manufacture. A variety of processes are used in the manufacture of Inorganic Pigments (SIC 2816); thus, waste minimization strategies must be process-specific. A good example of this variety is the production of titanium dioxide, which is made via the chloride process and the sulfate process. The chloride process produces a number of tail gasses containing chlorine residual that must be carefully treated, while the sulfate process produces waste water containing sulfur derivatives and a larger number of toxic metals. Waste streams containing metals such as barium, lead, and chromium are problem for this industry; such streams are often shipped offsite for disposat (EPA 1982).

Molten Salt Production. Metal chlorides, a primary product of Industrial Inorganic Chemicals, nec (SIC 2819), are produced by reacting a metal with an acid such as hydrochloric acid, sulfuric acid, or nitric acid. Once the metal is dissolved, the solution is purified and then concentrated via evaporation. Upon cooling, the salt precipitates from the solution for final recovery. Toxic metals are often removed during the purification step, thereby creating a metal-bearing sludge. Free chlorine is often present in the waste water and may result in chiorinated air emissions. Waste acids and 
salts are created which are often disposed of by underground injection. Metal-bearing wastes for land disposal include chromium and manganese compounds which are likely created during their processing to metal powders.

\subsection{PAPER AND ALLIED PRODUCTS (SIC 26)}

SIC 26 generates 6 wt\% of al1 TRI releases and transfers. Over 71 wt\% of the wastes generated by SIC 26 are generated by SIC 2611 (Pulp Mills), SIC 2621 (Paper Mills), and SIC 2631 (Paperboard Mills). According to the 1989 TRI database, the primary emissions are methanol, chloroform, sulfuric acid, hydrochloric acid, and other organo-chlorines. Almost all of these compounds are created during pulping and pulp bleaching--the process that converts brown pulp to white pulp. Methanol may be generated by reactions of lignins with cooking liquors.

\subsection{PETROLEUM PRODUCTS (SIC 29)}

SIC 29 generates 2 wt\% of a11 TRI releases and transfers. SIC 2911 (Petroleum Refining) generates 98 wt\% of the emissions from SIC 29, which include ammonia, toluene, xylene, benzene, manganese compounds, nickel compounds, and lead compounds. Most of the organic emissions are to the air, ammonia emissions are to underground injection, and metal emissions are to land disposal.

The most complete listing of refinery wastes was compiled by the American Petroleum Institute (API) in 1991 (API 1991). The sources of these wastes include tank botioms, spent catalysts, waste water treatment sludge, cooling tower sludge, cleaning solutions, and oil-contaminated soils. According to EPA (EPA 1980), other sources include catalyst dust from combustion of coke deposits on catalytic cracking catalysts, cooling water contamination from leaking heat exchange equipment, and fugitive $V O C$ emissions from leaking process equipment.

The current focus of waste minimization in the petroleum industry is on recycling and reuse. API, the National Petroleum Refiners Association (NPRA), 
and the Petroleum Environmental Research Forum (PERF) are working cooperatively to document waste minimization opportunities and the corresponding economic benefits.

\subsection{PLASTICS (SIC 30)}

SIC 30 generates 4 wt\% of all TRI releases and transfers. The largest generator is MisC. Plastic Products (SIC 3079). Most of these are air emissions of solvents like acetone, methanol, methyl ethyl ketone, and dichloromethane. The manufacture of most plastics begins with polymerization of a gaseous and liquid monomer. It involves an enclosed reaction, a drying step, and a thinning or forming step. Major sources of emissions include polymerization reactions and $V O C$ emissions during drying, storage, and handling of resins (EPA 1980).

\subsection{PRIMARY METALS (SIC 33)}

Approximately 14 wt\% of all TRI releases and transfers are generated by the Primary Metals Industry. Seventy-eight percent of the waste generated by SIC 33 is generated by Blast Furnaces (SIC 3312), Primary Nonferrous Metals, nec (SIC 3339), Primary Smelting and Refining of Copper (SIC 3331), and Secondary Smeliing and Refining of Nonferrous Metals (SIC 3341).

Possible sources of waste in SIC 3312 include VOC emissions from cokemaking, slag and sintering waste, air emissions of various alloying elements, and tramp metals from adding contaminated steel scrap to steel-making furnaces. Steel industry waste waters contain significant levels of toxic metals including chromium, copper, lead, nickel, zinc, and others. These metals are often removed by precipitation and must then be disposed of as solid waste.

Over 58\% of the wastes from SIC 3339 are air emissions of chlorine and hydrochloric acid generated during the production of primary magnesium. Another $30 \%$ of SIC 3339 wastes are lead and zinc releases to land, presumably from lead smelting and refining. Over $98 \%$ of the emissions from SIC 3331 are copper and other metal compounds from primary copper production. Over $72 \%$ of 
the waste from SIC 3341 consists of offsite transfers of aluminum dust and aluminum oxide presumably from secondary aluminum smelting, refining, and extrusion.

\subsection{TRANSPORTATION EQUIPMENT (SIC 37)}

This classification includes establishments engaged in the manufacture and assembly of complete passenger automobiles, trucks, commercial cars, and buses, and a variety of motor vehicle parts and accessories. Over 4 wt\% of all TRI releases and transfers are generated by this industry. Approximately $45 \mathrm{wt} \%$ of the wastes generated by this industry are generated by Motor Vehicles and Car Bodies (SIC 3711) and Motor Vehicle Parts and Accessories (3714).

The production of automobiles and trucks is a complex process that includes a number of process steps that produce wastes. Over $50 \%$ of the TRI releases and transfer's are airborne emissions of organics such as xylene, methanol, and acetone. The Motor Vehicle Manufacturers Association surveyed the wastes generated by this industry in 1987 and identified the following sources of solid wastes: waste water treatment sludge, paint sludge, and bonderizing sludge. These sludges contain methylene chloride; benzene; toluene; methyl ethyl ketone; chlorobenzene; ethylbenzene; 1,1,1 trichloroethane; and TCE.

\subsection{ELECTRONICS (SIC 36) AND METAL FINISHING (SIC $34,35,38,39$ )}

Approximately $10 \mathrm{wt} \%$ of total TRI releases and transfers are generated by a combination of electronics and metal finishing industries. The electronics industry includes a wide variety of processes and products including electron tubes, semiconductors, integrated circuits, capacitors, resistors, and printed circuit and wiring boards. This industry is highly fragmented with as many as $50 \%$ of the facilities owned by independent producers.

Wastes generated by SIC 36 include: 1) sulfuric acid/peroxide solutions from the removal of copper from printed circuit boards, 2) non-halogenated solvent in photoresists, 3) freon from drying of completed components and $1,1,1$ trichlorethane in degreasing of components, 4) alkaline solutions from 
pre-plate cleaning of parts and stripping of photoresist, and 5) metal-bearing solutions from copper and solder plating of printed circuit boards. The diversity of waste streams 1 isted above is generated at relatively high volume per unit of production (Foecke 1988).

Standard industrial categories in the metals finishing industry include Fabricated Metals Products (SIC 34); Machinery (SIC 35); Measuring, Analyzing, and Controlling Instruments (SIC 38); and Miscellaneous Manufacturing Industries (SIC 39). These industries include over 47,000 firms (of which less than 6,000 were represented by TRI data in 1988) and at least 45 production processes including plating, coating, machining, laminating, and degreasing. Waste streams generated by the industry include 1) process rinse waters with dilute concentrations of metals, oils, solvents, cyanide, and other process bath chemicals, 2) waste water treatment sludge containing metal salts and oils, 3) cutting tool or grinding wheel lubricants consisting of petroleum or animal blends, stable emulsions of oil and water, and semisynthetic products, 4) contaminated solvents from cleaning operations, and 5) spent plating solutions containing high levels of heavy metals (Hunt 1988).

The recovery of metal-bearing solutions so that they can be returned to the plating bath has been a high priority for the electronics and metal finishing industries. Available technologies include evaporators, electrodialysis, electrolytic metal recovery, ion exchange, and reverse osmosis, although technical problems are associated with each of these techniques (Hunt 1988). Despite the availability of technology, a speaker at a recent EPA conference on waste minimization reported that a large portion of plating waste sludge is going to Chemical Waste Management to be converted to cement.

\subsection{CONCLUSIONS}

Based on the review of top industrial waste generators, waste minimization efforts are needed for the following producers of chemicals: Chemicals (SIC 28) and Petroleum Refining (SIC 29). Sources of waste from these SICS include:

- fugitive $V O C$ emissions and spent metal catalysts during manufacture of industrial organic chemicals and from petroleum refining 
- ammonia emissions during petroleum refining and the production of nitrogenous fertilizers

- chlorine emissions during molten salt production, inorganic bigment manufacture, and manufacture of chlorinated solvents.

- relatively innocuous acids/bases/salts emissions to water.

Many salts are being gradually de-listed. Cost-effective recovery of waste acids and salts potentially represents a research need. In terms of air emissions, the initial focus must be on reducing the volatile organics. These are released as both fugitive and point source emissions because of their widespread use in many industrial sectors. Near-term research efforts to control fugitive emissions and longer-term efforts to replace some of these hazardous chemicals from routine use are warranted.

In addition, heavy users of chemicals in a variety of industrial sectors generate a significant amount of emissions: Primary Metals (SIC 33), Electronics (SIC 36), Transportation (SIC 37), Paper (SIC 26), Plastics (SIC 30), and Electronics and Metal Finishing (SICS 34, 35, 36, 38, 39). Promising efforts for reducing emissions for these SICs include: 1) recovery and reuse of solvents, metal-contaminated solutions, and waste oils, 2) alternatives to solvent-based processes for polymerization, resin thinning and the cleaning, etching, painting, and joining of parts, and 3) alternatives to chlorine for metal refining and pulp bleaching. 


\subsection{RESEARCH AND DEVELOPMENT NEEDS ASSESSMENT: THE INTERVIEW RESULTS}

The results of the waste characterization task served as the basis for discussions with: 1) federal entities, 2) industrial trade associations, 3) specific industries, and 4) environmental advocacy groups to delineate the appropriate waste minimization $R \& D$ role for $A I C$ and to identify broad R\&D areas that AIC could support in developing the technology base. The interviews were conducted either by telephone or direct visits. This chapter summarizes the relevant information obtained through the interviews. A 1 ist of organizations that were interviewed is included in Appendix $C$.

\subsection{FEDERAL ENTITIES}

Interviews were conducted with the following federal entities:

- The Environmental Protection Agency (EPA)

- The Office of Technology Assessment (OTA)

- The Council on Environmental Quality (CEQ).

EPA is the lead federal agency with responsibility for administering the nation's environmental programs. Thus, collaboration with EPA will be criti. cal to the success of a DOE waste minimization program. The CEQ (which advises the President) and the OTA (which advises the Congress) have monitored progress in waste minimization for some time and are well suited to provide guidance to AIC.

Within EPA, interviews were conducted with several organizations, including: 1) the Office of Pollution Prevention, 2) the Hazardous Waste Superfund Division, 3) the Office of Engineering Technology, 4) the Office of Toxic Substances, 5) the Risk Reduction Research Laboratory, and 5) the Waste Minimization Research Branch.

Effective waste minimization prograns require a thorough understanding of the characteristics of the wastes generated and their treatment and disposal costs. The costs/benefits of process modifications or recycling options to reduce waste generation can then be compared to the baseline treatment and disposal costs. A cost/benefit analysis for the existing process (including 
any treatment and disposal costs) should be compared with similiar analyses for all pottential waste minimization technollogies. Such analyses can serve as the bastis for a waste minimization research agenda!. Both EPA and OTIA concur on thiis approach.

EPA!'s we 717-publicicized Industrial Toxics Project and Green Lighits Project are good exampiles of this approach. In both cases, industry is working with EPA to impliement current technollogy to improve efficiency (in the lighting: project) and reduce toxic emissions (in the toxics project). Because these types of readily implementabile programs wil7 occupy. EPA's resources for the foreseeabile fucure, EPA wilit not be in a position to undertake any long-term, pre-competitive research in waste minimization for next-generation technology development. Instead, EPA would prefer to promote the implementation of technologies developed elsewhere to achieve the desired waste minimization goa7s. Thus, EPA has gladly taken on the role of implementing efficient. 1 ighting technologies developed by DOE's Office of Building Technologies (OBT) in the Green Lights Project. EPA is also working with DOE to promote the implementation of many technologies that DOE is developing to effectively deal with the wastes generated at its own production facilitities.

Waste minimization is a continuous process. As today's technologies are implemented to achieve reductions in emissions, new technologies will be required to continue the advances. For exampile, a successful Industrial Toxics Project witl lead to demands to continue the effort and to reduce the emissions further. The concept of "Total Quality Management" is very appropriate in this regard. EPA is promoting the use of such a concept in dealing with the ongoing process of waste reduction, and industry is gradually buying in. OTA is also supportive of this approach. Thus, both EPA and OTA acknowledge the need for an ongoing long-term waste minimization reseanch program, which is lacking at present. A collaborative AIC/industry program in precompetitive research and development of waste minimization technologies is endorsed by both EPA and OTA. This program must be coordinated with EPA to ensure a proper focus with respect to current environmental regulations.

The CEQ also acknowledges the need for long-term research in this area. The CEQ emphasizes that the program must be directed by a product 1 ife-cycle 
anajysis where the costs of the major environmental externalities are accurately factored in. The linkage between efficiency improvements and waste minimization is important to establitish, and one must be carefuil in doing so since there are many instances where the two objectives may be in confilict. For example, some technollogies that could reduce waste production may indeed be more energy-intensive than the processes they would replace. A methodollogy: to assess such benefits/costs should be develloped in order to conduct a thorough analysis before selecting projects for funding.

The interviewees were unanimous that waste minimization concepts are not wel1 suited for a regulation-driven implementation approach. The key to success will be the formation of effective partnerships with industry and the environmental community in setting goals for waste minimization and then implementing them with innovative new technologies. The proposed research program, therefore, must be a colliaborative endeavor. The broad concepts that: the interviewees considered important in structuring this program are summarized below:

1. The focus of the planned collaborative program should be those technologies that are not central to presently used products or processes, since few companies witi actively search for technologies that will make their current products obsolete.

2. The government must anticipate the commodities of the future (e.g., composites, ceramics) and develop clean manufacturing processes. It should a 7 so develop standardized life-cycle analys is procedures for competing products so that informed purchasing choices can be made. Such analyses would a 750 form the basis for mandating product stewardship plans for products that pollute the environment.

3. Pollution prevention research should focus ai least as much attention on the users of toxic chemicals as on the manufacturers. Textiles, printing, photo processing, and electronics are good examples.

4. The reauthorized Clean Air Act will impose new controls on ozonedepleting chemicals, air toxics, and acid rain, as well as calling for new alternative and reformulated fuels. The Act will regulate emissions of 189 toxic or carcinogenic chemicals through the installation of Maximum Achievable Control Technology during the next 10 years and then apply further measures to control residuat risk. AIC's technology development program could focus on waste reduction opportunities with these 189 chemicals. 
5. The emphasis on energy efficiency and competitiveness is very important. We must move stop viewing environmental concerns as added costs to industry. Rather, we must addiress those concerns that are both a profit to industry and a benefit to the environment.

\subsection{THE ENVIRONMENTAL COMMUNITYY}

The environmental advocacy groups have played a significant role in establishing environmental policies in this country and are very aggressive in ensuring that these policies are implemented. This has often involved contentious litigation where the executive branch or specific industries have been the defendants. In general, the relationship between the environmental adivocacy groups and industry has been adversarial, alithough there are some recent indications that a limited amount of cooperation is beginning to occur.

The following groups interviewed in this study have taken the lead in promoting waste minimization and have started working with industry to promote an increased focus in reducing emissions at the source:

- National Witdifife Federation

- Greenpeace

- National Toxics Campaign Fund

- Environmental Action Fund

- Massachusetts Public Interest Research Group (PIRL)

- United States PIRG

- The Environmental Defense Fund.

These groups agree that corporate commitments to deal with environmental issues have increased. They intend to monitor how these comitments are translated into specific actions. The initial results are very promising, and the environmental groups sincerely hope that industry will sustain its efforts.

Cooperation between these environmental groups and industry is gradually evolving. As industry begins to accept the legitimate environmental concerns of the general public, the advocates are accepting that competitive pressures 
on industry are very important. A balanced approach is needed. The National Wildlife Federation has taken a strong lead in this area. Waste reduction bills pending in Congress are factoring in industry concerns regarding competitiveness.

The environmental groups favor a strategy of working with the users of chemicals in various industrial sectors to promote waste reduction technologies, and also to put pressure on the chemicals industry to reduce the production and use of hazardous chemicals. They are interested in supporting technical projects that are of interest to both industry and the environmental community and working jointly to bring them to a successfut conclusion.

Long-term technology development is recognized as essential for a sustained waste reduction effort. EPA does not have the resources to support such a program, and the environmental community feels that industry does not have a strong inclination to undertake a massive effort on its own. A colTaborative R\&D program between DOE and industry wi11 be welcomed by the environmental advocates, as long as they are consulted on the R\&D priorities. The environmental community recommends the following general areas for research on waste reduction:

1. Chlorinated and fluorinated hydrocarbons are considered prime areas for waste reduction R\&D. Alternatives to these chemicals must be developed. Substitutes must be developed for chlorine in drinking water and the pulp and paper industry.

2. Reducing industry's use of hazardous organic solvents is another area where there is strong support for an R\&D program. In general, industries (particularly in high-technology sectors) that are heavy users of chemicals such as solvents have taken the lead in waste reduction programs.

3. The linking of energy efficiency and waste minimization is considered to be desirable. However, some of the interviewees indicated that an over-emphasis on competitiveness may be counterproductive. They suggested that industry may use this as an argument as to why they should only be required to do a minimal amount of waste reduction.

4. The Environmental Defense Fund categorized mining as the single human activity in the United States with the greatest need for technological solutions. A key emphasis of those interviewed 
seemed to be the need for developing in situ mining and resource extraction (perhaps facilitated by microbes or synthetic complexing agents).

5. The Environmental Defense Fund is very concerned about pollution from agriculture. Water quality data indicate that erosion and runoff from agricultural lands are key non-point sources of surface water pollution. The sediments carry salts, heavy metals, fertilizers, pesticides, and bacteria to surface waters. Agricultural pesticides and fertilizers are significant sources of groundwater pollution as well.

6. Because of high-purity requirements, pharmaceutical manufacturing generates a large volume of waste per unit of output. Efforts should be directed at assisting this industry in deploying separations technology developed elsewhere.

7. The petroleum industry is not paying enough attention to developing advanced separations technology and improved catalysts. Research is necessary on petrochemical processes that reduce waste generation.

8. High-volume separations technology is needed to treat wastes being disposed of by underground injection.

\subsection{TRADE ASSOCIATIONS}

The waste characterization task identified SIC codes 28 and 29 as industrial sectors where AIC should consider targeting its efforts. Therefore, the following two trade associations representing these industries were selected for interviews:

- The Chemical Manufacturers Association (CMA)

- The American Petroleum Institute (API).

The objective ir these interviews was to obtain an overall industrial viewpoint on key problems and waste minimization technology needs. In addition, other trade associations with an interest in waste reduction were interviewed, including:

- The Water Pollution Control Federation (WPCF)

- The Air and Waste Management Association (AWMA)

- The Council for Solid Waste Solutions (CSWS). 
The chemicals and petroleum industries have recognized the nead to be perceived as environmentally responsible. They are actively undertaking waste minimization efforts and publicizing their accomplishments. The two respective trade organizations, CMA and API, are following their members' wishes and undertaking a proactive role in promoting waste reduction.

CMA's centerpiece is the "Responsible Care" Program, which is based on the following two guiding principles: 1) "To make health, safety, and environmental considerations a priority in our planning for all existing and new products and processes," and 2) "To extend knowledge by conducting or supporting research on the health, safety, and environmental effects of our products, processes, and waste materials." Corporate commitment to the program has been excellent, as evidenced by strong statements from the Chief Executive Officers of major chemicals firms such as DuPont, Dow Chemical, and $3 M$ to pursue specific emissions reduction targets. These commitments are gradually being translated into specific actions. Many innovative projects are being undertaken at the local level with participation from industrial plant managers and state and 10cal authorities. Strategies for effective waste reduction are being discussed, developed, and implemented. The results obtained are being shared informally among the many plants.

Similariy, the API, which represents the U.S. petroleum industry, has formed waste minimization and pollution prevention task forces to develop, implement, and promote technologies to achieve these goals. The waste minimization task force is 2 years old, and it is currently tracking 28 waste streams within 6 major categories. A significant amounc of waste minimization has already occurred in the industry, triggered by the strong incentive to maximize yields and minimize costs. Many of these efforts have been based on current technologies and are essentially process improvements and modifications in refinery housekeeping.

The pollution prevention task force was formed more recently. The intention of this task force is to take a "grass roots" look at a refining operation, determine if there is better technology to reduce pollution, and propose innovative solutions and radical process alternatives that would minimize pollution. An identification of technology needs is expected to 
result from this effort. AIC must maintain a close relationship with this task force so that their emerging recommendations are properly factored into the planned AIC program.

Both CMA and API agree that there is a need for federal involvement in supporting generic pre-competitive research to develop next-generation waste minimization technologies. The goals of a collaborative government/industry program should be to improve process efficiency and minimize waste generation. The near-term solutions are already being implemented, and the time is right to consider the next generation of problems and to develop approaches for solving them. The industrial members of CMA and API are interested in a research program that has clearly defined objectives for each phase. The industry members should be involved early in designing the program. This will provide the time necessary to build a consensus regarding research priorities. In the case of the petroleum industry, coordination with PERF was highly recommended. PERF funds R\&D programs related to waste treatment and reduction for multiple API members, based on their individual interests.

The planned AIC program should avoid R\&D directed toward specific process modifications. This type of research would require proprietary information, and industry would not want any DOE involvement with their proprietary processes. Rather, the emphasis should be on generic research that would develop a technology base for specific modifications to be done by industry.

As new technologies are being developed, regulatory pressures to implement them may arise before the technologies are ready. Industry is very susceptible to such pressures and may want safeguards in that regard. One trade association strongly suggested that from the inception, EPA become a partner in this cooperative program so that they are aysure of the status of the technology development efforts and will be able to assist in mitigating such pressures. Another trade association also underscored the issue, but concluded just the opposite. That is, they stated that EPA should not be involved in the technology development program so that they will not be tempted to force implementation of new technologies prematurely. The trade associations also suggested that the state and local authorities should be 
included in the program, since they are already playing an important role in promoting industrial waste minimization programs.

The linkage between competitiveness and waste minimization is important. DOE can play a strong role in this issue by properly defining the mission of the national laboratories in addressing waste minimization problems and in undertaking both technology development and technology transfer. The European and Japanese governments and companies have become very active in this area. The lack of natural resources has led to evolution of a Japanese corporate culture that prompts them to design processes that are efficient and produce minimal amounts of waste. The European "green" movement has forced guvernments to become active participants in waste reduction efforts and to promote "clean products." Thus, from a competitiveness standpoint, the trade associations believe that the United States must act soon and that a DOE program can be an additional resource for U.S. industry to develop and maintain a strong competitive position in waste reduction technologies.

The discussions with WPCF were 1 imited to groundwater contamination issues and focused primarily on their recently released report (Water Quality 2000 1991). The key sources of groundwater contamination from industrial operations include: 1) underground injection of industrial waste, 2) toxic chemicals being leached into the groundwater from leaking underground tanks and waste disposal sites, 3) synthetic organic chemicals contaminating shallow aquifers, and 4) spills from petrochemical transportation and storage. Funoff and dissolution of industrial air pollutants into surface waters are key non-point source areas of concern.

To date, industrial compliance with the effluent limitation guidelines is good. Ninety-three percent of major industrial dischargers are meeting standards. However, there are gaps in water quality legislation, so that four out of five direct industrial discharges are not regulated. These relate primarily to non-point sources such as storm water runoff and sewer overflows. Biological criteria for establishing effluent 1 imitations are also lacking.

In the area of science and technology, the Water Quality 2000 committee cites a need for new cost-effective procedures and equipmen. to 
- detect and remove minute quantities of toxic contaminants from drinking water (few market incentives exist for private-sector development of such technology)

- control runoff from urban and rural lands

- help industry make the process design modifications needed to reduce the generation of pollutants.

\subsection{INDUSTRIAL INTERVIEWS}

Interviews were conducted with 19 industrial firms that operate primarily within the industrial sectors targeted in this study. A listing of all the firms is shown in Appendix $C$. Interviewees included researchers, plant operators and managers, environmental compliance personnel, and decision makers responsible for setting company objectives. The interviews show that, in general, there is a strong corporate commitment to reducing emissions and that operating personnel are experiencing strong pressure from management to minimize waste generation.

Waste minimization efforts are relatively new in many of these organizations. Most of their environmental research dollars are still being spent on end-of-pipe treatment technologies to ensure compliance with existing and upcoming federal and state regulations. However, the importance of waste minimization is being recognized, and many of these companies are instituting procedures to reduce the amount of wastes they generate.

Much of the work in waste minimization involves better housekeeping and making process modifications with currently available technology to reduce emissions of hazardous wastes. For example, many industries indicated voluntary participation in leak detection and prevention programs, solvent substitution and recycling programs, and technology development to convert wastes to valuable products and recover reusable materials. A key accomplishment to date as been the attempts to systematically identify all the hazardous and toxic materials used in the various processes and the nature of emissions of these materials from their plants. This type of database then allows the companies to target areas to commit resources for waste reduction. 
Economics is the primary driver for industry to promote pollution prevention. Industry must be convinced that it is cost-effective to undertake the investment required and that an adequate return can be realized. There is a need for process simulation technologies that factor in options for pollution prevention and accurately estimate the environmental costs of existing process as well as the cost advantages associated with proposed modifications. Such methodologies are not available at present, although rudimentary modeling efforts are beginning to emerge. Developing standardized methodologies for such purposes is a desirable goal, and many in industry suggested that it should be a goal of DOE-supported research. It is difficult for industry to develop such standardized methodologies on their own, both from the standpoint of cost as well as credibility.

A typical example of a modeling effort would be to optimize refinery operations to lower the benzene content of gasoline and, at the same time, increase the output of methyl ternary butyl ether (MTBE), an octane enhancer. The reduced octane rating resulting from the lower benzene content will be compensated for by the higher production of MTBE. Such an optimization process could result in gasoline having the same octane rating, but containing much less benzene. Preliminary indications are that such a process will not only contribute substantially to pollution prevention, but may also be very cost competitive. The critical research issue that emerges from such an analysis is the need for new catalysts with the proper activity and selectivity for the proposed changes. A successful program of this type will be beneficial in reducing emissions of benzene to the atmosphere. This example illustrates the interactive process between this type of process simulation and the identification of research opportunities in waste reduction.

There is a clear consensus among the interviewees that a strong federal role in waste minimization technology development is warranted. The federal government should work with industry on pre-competitive research on common problems and not on projects that provide specific advantages to individual companies. The mission of AIC is welcome, which is to focus on generic applied research to develop a technology base in waste minimization that also addresses energy efficiency and competitiveness. This program should also 
attempt to develop and promote a scientific basis for environmental decisionmaking. Many industries perceive that they are being over-regulated relative to the risks imposed by their emissions. The program must also emphasize the important role of technology transfer of waste minimization technologies developed by and for the government. A government/industry consortium pursuing these research goals would be an appropriate vehicle to accomplish them.

The research content of the program must be established jointly with the industrial participants and DOE. These interviews identified some broad areas where there is general consensus that a federally supported RaD effort is warranted, including:

- process modifications to reduce water usage and promote the recycling of water

- new catalysts and process optimization to reduce unwanted side reactions and improve conversion efficiencies

- substitutes for halo-organics in the pulping industry and in the solvents industry

- improved process technology to minimize VOC emissions

- process simulation methodologies to optimize product output with proper accounting for environmental impacts

- improved catalysts, recycling and reuse of spent catalysts, and biocatalysis of industrial processes

- optimal combustion of transportation fuels, including alternative fuels optimized auto exhaust catalysts, anc reformulated gasolines.

- separations technology to remove trace contaminants from highvolume waste streams. 


\subsection{TOPICAL ASSESSMENTS}

There is voluminous literature on waste minimization that discusses: 1) the potential advantages of pollution prevention, 2) specific case studies, 3) government and industry roles, and 4) the research and development needs. This study does not attempt to provide a comprehensive summary of all the pertinent literature. Rather, in this chapter we summarize the recommendations of three major studies in waste minimization and discuss their relevance to the proposed AIC waste minimization R\&D philosophy.

\section{\.1 THE NATIONAL ENERGY STRATEGY}

The role of DOE in solving environmental problems is an emerging one. In public comment detailed in the interim National Energy Strategy (NES) report (DOE 1990b), several environmental issues were addressed: air quality, global environmental issues, waste management, and impacts of energy production on water and land use. A significant portion of the study addressed environmental pollution as it relates to energy production and use.

Waste minimization was specifically addressed in the NES report (DOE 1990b). The need for significant pollution prevention and waste minimization activities by U.S. industry was recognized and supported. Public comments dictating the type of role DOE should play included:

- Minimize waste production by improving the efficiency of energy technologies and end-users.

- Support the development of alternative energy technologies such as renewable energy.

- Promote research into waste reduction and waste minimization practices that might be used by energy industries and end-users.

- Ensure that costs of compliance with more stringent regulations do not shift industry investments to outside the United States where environmental regulations are less stringent.

- Develop policies so that social costs of disposal are included in industrial products and practices. 
The production of energy, especially from the combustion of fossil fuels, was recognized as an important source of waste. Air emissions are cited as the principal problem, although liquid and solid wastes from petroleum processing and the production of ash from coal and municipal waste combustion are other concerns. Development of more efficient combustion equipment and vehicles (to reduce the amount of waste produced per unit of work provided) and the development of solar-based energy sources (solar thermal, photovoltaics, biomass, and wind) are still seen as the major challenges.

Several specific guidelines for the technical content of DOE programs in waste minimization were provided in the interim NES. Some key environmental problems of public concern in the private sector are

- benzene and diesel emissions from motor vehicle use

- air toxics from chemical plants and refineries

- anthropogenic contribution to "greenhouse" gases

- generation of drilling fluid wastes

- $0 i 1$ recovery from sludge/use of slur'ge as coker feedstock.

The waste characterization task conducted as part of this study confirmed many of the issues raised in the interim NES. These issues were also mentioned in our interviews of experts from industry, trade associations, and the environmental community. The proposed AIC program that may evolve from this analysis will be consistent with the goals and objectives of the NES.

The final NES (first edition) was published in February 1991 (DOE 1991). The final NES states that DOE will increase funding of cost-shared research and technology development. DOE will target the cost-shared effort to key areas with potential for substantial energy reduction.

Initially, DOE will target chemical processes because of the large amounts of wastes that they produce and the large investments that are being made in pollution control activities ( $\$ 4.2$ billion in 1988). Additional industries, such as the petroleum industry and the pulp and paper industry, will follow as additional analysis is done (DOE 1991). 


\subsection{ENGINEERING RESEARCH BOARD STUDY ON DIRECTIONS IN ENGINEERING RESEARCH}

The Engineering Research Board of the National Research Council (1987) conducted a study to evaluate the role of engineering research to meet national objectives. This exhaustive study addressed a wide spectrum of issues relating to engineering research and identified a number of critical research areas, including waste treatment and waste reduction. Some of the relevant systems studies the Engineering Research board recomimended are to

- couple industry knowledge of waste minimization needs to existing scientific knowledge and technology developed in support of energyefficiency objectives

- develop design tools for evaluating alternative technology concepts that would incorporate environmental constraints along with thermodynamic and cost factors

- conduct comparative assessments of the energy and cost implications of waste reduction versus waste management approaches

- undertake a systematic assessment of 1 ife-cycle costs, energy flows, and wastes generated by industrial products and processes (including waste treatment) to determine critical technology barriers

- perform socio-economic studies of various strategies for minimizing waste from disposal of pre-owned products (1 ife-extension and reuse/collection and recycle)

- develop strategies for infrastructure changes so that byproducts of one operation become raw materials for another.

These studies are very relevant as one attempts to establish a long-term research program with industrial participation. AIC should consider some of these studies as components of its planned program.

\subsection{NATIONAL RESEARCH COUNCIL STUDIES}

At the request of the EPA, the National Institute for Environmental Health Sciences, and the Agency for Toxic Substances and Disease Registry, a workshop was held on May 8-9, 1990, in Annapolis, Maryland, under the auspices of the National Research Council's Board on Environmental Studies and 
Toxicology. The purpose of the workshop was to identify research needs in the area of applied social sciences to assist in developing waste reduction strategies for U.S. institutions.

Two general areas of research needs were identified by works.iop participants: 1) measurement of waste reduction, and 2) investigation of institutional and behavioral barriers and incentives. These needs have not been addressed by federal programs. They are mentioned below because it may be most effective to integate such research with technical objectives (COAERD 1990). The segment on measurement indicators is particuliarly important for the proposed AIC waste minimization program. Recommendations for research mentioned by the panel include:

- post-production waste implications of major commodity chemicals and other products or materials over their lifetimes

- Tife-cycle costing methodologies that include waste reduction and waste reduction factors that must be considered for making capital investment decisions

- measurement of the success of waste reduction efforts. 


\subsection{CONCLUSIIONS AND RECOMMENDATIONS}

Waste minimization is emerging as a central theme in dealing with the nation's environmental problems. It is an alternative to the currenit relliance on implementing industrial reguliations. These regullations have encouraged industry to commit its resources to developing "end-of-pipe" treatment technologies and have also created an adversarial relationship between industry and government in environmental compliance. Waste minimization provides an opportunity to use a cooperative approach through which industry, government, and the environmental community can work together to minimize environmental problems. EPA has taken the lead to promote the concept and industry has willingly embraced it.

Curreni industrial waste minimization efforts concentrate on good housekeeping and process modifications to reduce waste generation and to recycle whatever is generated. Success has so far been very good. However, waste minimization is a continuous process. Today's success generates needs for further improvements tomorrow. Innovative technologies are vital if the process is to continue unabated.

Unfortunately, research to develop lionger-terin next-generation technology for reducing wastes is lacking. Industry does not have the necessary resources to undertake such a massive effort. EPA, however, is committing its resources to the tasks at hand, namely to promote the waste minimization concept and to ensure that near-term waste reduction efforts are successful. There is a pressing need for a major federal role for research and development in this area. Our interviews indicate such a role should be limited to precompetitive generic research which industry can use to develop specific products and processes for their own plants. This is a unique opportunity to bring together federal regulators, industrial representatives, and the environmental community to guide such a research program. It would be a collaborative effort with cost-sharing between industry and government.

This type of collaborative program is within the scope of AIC's mission. Also, its capabilities and existing working relationships with the chemicals and petroleum industries are weil suited for initiating such a program. The 
strong support of the key players, both in the federal sector and in industry, is a testimony to the relevance of the program. The additional requirements of 1) improving energy efficiency, and 2) enhancing the competitive position of U.S. industry were regarded by the interviewees as very desirable goals. Finally, it is important to note that the environmental community supports such an R\&D effort. Thus, if this program is initiated, it will be a unique example of the federal government, industry, and the environmental community working together to solve pressing environmental problems.

The objectives in phase 1 of this study were to identify some broad areas that are of interest to industry and to the environmental community and to explore which of these areas can be best served by AIC utilizing its. existing capabitities. The topics that emerged from our interviews are:

- analytical tools

- process modifications

- new materiats

- product substitution

- resource recovery

- monitoring systems

- separations.

Each of these topics is summarized briefly below.

\subsection{ANALYTICAL TOOLS}

There is a need for modeling tools to simulate industrial processes. The objective of these simulation methodologies would be to optimize the process both for product output as well as the reduction of generated waste. These tools must take full account of resource utilization, waste recovery, and waste treatment to provide decision-makers with a realistic picture of costs and benefits of the entire process. Many industrial process simulation programs are now available, but apparentily none of them can properly account. for environmenta? impacts. 
AIC has considerable expertise in developing modeling tools. One such example is the Catalysis-by-Design Program, where computer simulation technologies are being refined to aid the search for new catalysts. These capabilities can be used to develop the types of simulation techniques discussed here. A by-product of these modeling activities will be the identification of critical research improvements that are necessary in the long term.

\subsection{PROCESS MODIFICATIONS}

A major category of waste in the chemicals and petrochemicals industries is the unwanted by-products of chemical reactions. Most of the reactions in the various processes used in these industries employ specific catalysts. Improved catalysts are key to reducing unwanted side reactions.

AlC has a wealth of experience in catalysis research. It should consider broadening its research base in catalysis to understand the inefficiencies of current catalysts and to develop technology for efficient ones, thiss reducing the amount of wastes produced. Such a catalyst research program focused on waste minimization should include both chemical and biological catalysts. Biocatalysts may be very attractive in this regard; their specificity could potentialily reduce unwanted by-products substantialily.

The program could be expanded to include catalysts to convert wastes to more valuable products, technology to recover spent catalysts, and technology to extend the useful life of catalytic systems.

\subsection{NEW MATERIALS}

plastics are an integral part of our industrialized society. They are, however, energy-intensive in their manufacture, require many hazardous raw materials, and are, in many instances, extremely difficult to dispose of after. use. Current commercial plastics were developed to meet specific application requirements. Very 1 ittie attention was given to the environmental or energy consequences when plastics were being developed.

AlC can initiate a research program to develop the technologies neces. sary to produce polymeric materials that meet specific application needis but are less energy-intensive in their manufacture and are environmentally 
acceptable, both in terms of the raw materials used in their manufacture and the way they can be disposed of or recycled. Developing plastic materials with these types of characteristics is a challenging task. AIC can build on its experience base in polymer research to undertake generic applied research to lay the foundations for the development of new materials that meet the application requirements in an environmentally acceptable fashion.

\subsection{PRODUCT SUBSTITUTION}

Chlorine and chlorine-based chemicals such as the halo-organics are usually hazardous to the environment. However, these chemicals are, in many ways, essential to modern-day living. For example, chlorine is used in pulp bleaching to produce the white paper we have become used to. It is also used in the manufacture of poly-vinyl chloride (PVC), a commonly used construction material. Similarly, the halo-organics are still extensively used as solvents and degreasers. There are many other examples of hazardous chemicals that are now essential to our daily lives.

AIC should consider selecting at least one such chemical and initiating a research program to develop the basis for environmentally acceptable costeffective substitutes. The excellent working relationship AlC has with the chemicals industry and its expertise in chemical and bio-processing technologies will be assets in such a long-term program.

\subsection{RESOURCE RECOVERY}

Recycling is becoming increasingly popular and it will always be a critical component of any waste minimization effort. Unfortunately, most materials are recycled into lower-valued products than the originals. This is particularly true of many plastics. Also, many other materials are not. recyclable because of a lack of cost-effective technology. In addition to recycling, the broader area of resource recovery must receive more attention in waste minimization efforts. Recovering value-added products from waste and from used products is essential. Bioremediation of waste to render it harmless and to recover useful products is an area that needs greater focus. 
AIC can make a contribution to the general area of resource recovery. The objective of the program would be to develop the technology that would allow industries to develop cost-effective recovery processes for many of its wastes and also to recycle used products. AlC's capabilities in materials research and bioprocessing would form the basis of the program. In particular, it would address generic research on materials processing and forming technologies that will be relevant for resource recovery applications.

\subsection{MONITORING SYSTEMS}

Two types of monitoring technologies are required: 1) for better process control to improve efficiency and reduce waste, and 2) for better tracking of actual waste reduction achievements. Much work on sensor technologies is in progress, although it is not specifically directed toward waste reduction. Nonetheless, with minor changes, many sensor technologies can be modified for waste minimization applicatior,s.

AIC should consider entering this crowded field with caution. It should rely on the results of the analytical effort described above to identify very specific sensor requirements that are not being currently addressed. If such opportunities are identified, AIC can bring its materials and chemical processing capabilities to bear on addressing those needs.

\subsection{SEPARATIONS}

Technologies that separate small quantities of undesirable materials from a very large volume of fluid are critical in most waste reduction efforts. Some research is in progress in advanced separations technologies, but much remains to be done. This is especially true in the case of removing trace amounts of volatile organics from huge volumes of exhaust "air.

AIC currently does not have an active separations research program. However, it can build this capability based on its experience in materials and chemical processing technologies. A long-term research effort in separations technology is needed. 


\subsection{PHASE 2 OF THIS STUDY}

The broad research agenda outlined here will form the basis of a series of workshops with industry experts in phase 2 of this study. These workshops will develop a prioritized list of specific research topics that AIC can consider in a 5-year waste minimization program plan. This approach essentially will continue the "bottoms-up" strategy that we have employed so far to assess what role AIC should play in waste minimization research. Also, it will identify specific research areas that have the support of industry and the environmental community. Phase 2 efforts will also focus on addressing the current status of waste minimization programs within the DoD and attempt to identify areas where the planned AIC program can play a complementary role to the DoD efforts, and vice versa. 


\subsection{REFERENCES}

American Petroleum Institute (API). 1991. The Generation and Management of Wastes and Secondary Materials in the Petroleum Refining Industry: 1987-1988. API Publication 4530. Washington, D.C.

Bergland, R. L., R. R. Romano, and J.L. Randall. 1990. "Fugitive Emissions from the Ethylene Oxide Production Industry." Environmental Progress $9(1): 10-16$.

Citizens Fund. 1990. Manufacturing Pollution: A Survey of the Nation's Toxic Polluters, Washington, D.C.

Committee on Opportunities in Applied Environmental Research and Development (COAERD). 1990. Waste Reduction: Research Needs in Applied Social Sciences, A Workshop Report. National Academy Press, Washington, D.C.

Foecke, T. L. 1988. "Waste Minimization in the Electronics Products Industries." JAPCA 38(3):283-291.

Hunt, G. E. 1988. "Waste Reduction in the Metal Finishing Industry." JAPCA $38(5): 672-680$.

Moore, N. L., and G. L. Wilfert. 1987. "INDUST, An Industrial Data Base." PNL-SA-14740. Presented at the 9 th Annual Industrial Energy Conference, Houston, Texas. PNL-SA-14740, Pacific Northwest Laboratory, Richland, Washington.

National Research Council. 1987. Directions in Engineering Research: An Assessment of Opportunities and Needs. Engineering Research Board, Commission on Engineering and Technical Systems, National Academy Press, Washington, D.C.

Sanders, C. L. 1986. Toxicological Aspects of Energy Production. Macmillan Publishing Company, New York, New York.

U.S. Bureau of Census. 1987. Statistical Abstracts of the United States: 1988. (108 edition), U.S. Bureau of Census, Washington, D.C.

U.S. Department of Ecology. 1990. Capacity Assurance Plan for the State of Washington. Olympia, Washington.

U.S. Department of Energy (DOE). 1990a. Industrial Waste Gas Assessment. DOE/CE/40762-T2, U.S. Department of Energy, Washington, D.C.

U.S. Department of Energy (DOE). 1990b. Interim Report National Energy Strategy. DOE/S-0056P, U.S. Department of Energy, washington, D.C.

U.S. Department of Energy (DOE). 1991. National Energy Strategy.

DOE/S-0083P, U.S. Department of Energy, Washington, D.C. 
U.S. Environmental Protection Agency. 1980. Volatile Orqanic Compound (VOC) Species Data Manual. Second Edition, Research Triangle Park, North Carolina.

U.S. Environmental Protection Agency (EPA). 1982. Development Document for Effluent Limitation Guidelines, New Source Performance Standards and Pretreat ment Standards for the Inoraanic Chemicals Manufacturing Point Source Cat egory. PB82-265612, U.S. Environmental Protection Agency, Washington, D.C.

U.S. Environmental Protection Agency (EPA). 1984. Development Document for Effluent Limitations Guidelines, New Source Performance Standards and Treatment Standards for the Inorganic Chemicals Manufacturing Point Source Category. PB85-156446, U.S. Environmental Protection Agency, Washington, D.C.

U.S. Environmental Protection Agency (EPA). 1986. Report to Congress: Minimization of Hazardous Wastes. EPA 530/SW-86-033A, U.S. Environmental Protection Agency, Office of Solid Waste and Emergency Response, Washington, D.C.

U.S. Environmental Protection Agency (EPA). 1988. Future Risk: Research Strateqies for the 1990s. SAB-EC-88-040, U.S. Environmental Protection Agency, Science Advisory Board, Washington, D.C.

U.S. Environmental Protection Agency (EPA). 1989. 1985 National Biennial Report of Hazardous Waste Generators and Treatment Stordge and Disposal Facil. ities Requlated Under RCRA Volume I Summary. PB89-187645, National Technical Information Service, Washington, D.C.

U.S. Environmental Protection Agency (EPA). 1990. Pollution Prevention Research Plan - Report to Congress. EPA/600/9-90/015, Office of Environimental Engineering and Technology Demonstration, U.S. Environmental Protection Agency, Washington, D.C.

Water Quality 2000. 1991. Challenges for the Future. TTOLPD, Water Environment Federation, Alexandria, Virginia.

Wolf, K. 1988. "Source Reduction and Waste Management Hierarchy." JAPCA $38(5): 681-686$. 
APPENDIX A

HAZARDOUS AIR POLLUTANTS REGULATED UNDER TITLE III OF S. 1630 


\section{APPENDIX A}

\section{HAZARDOUS AIR POLLUTANTS REGULATED UNDER TITLE III OF S, 1630}

Table A.l contains the list of hazardous air pollutants subject to regulation under Title III of $S .1630$. The committee report accompanying S.1630 (Report No. 101-228, p. 147) states that the list was largely prepared by EPA and is identical to the list included in the President's 1989 proposed Clean Air Act Amendment bill (S.1490).

TABLE A.1. Hazardous Air Pollutants Subject to Regulation Under Title III of $\mathrm{S.1630}$

\section{Chemical name}

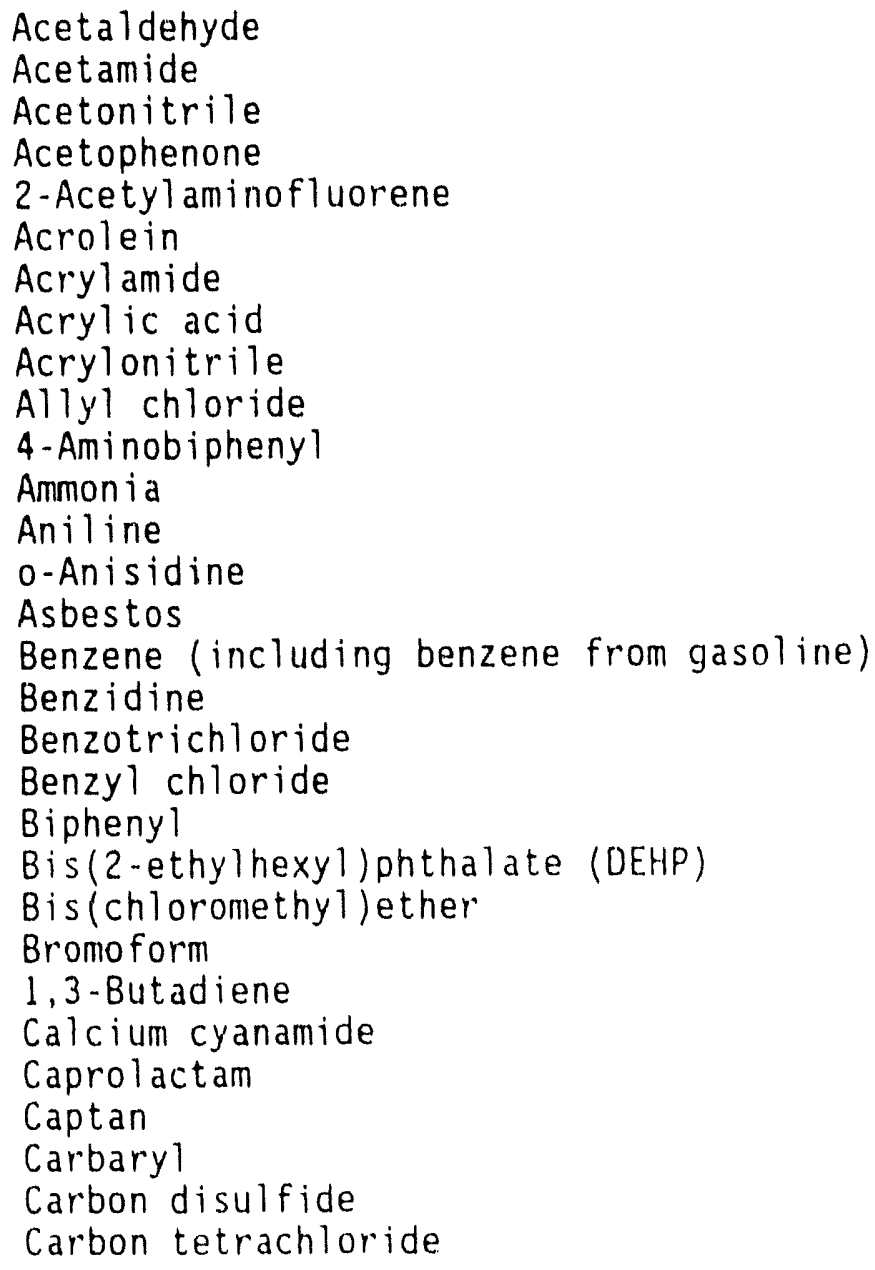


TABLE A.1. (contd)

Chemical name

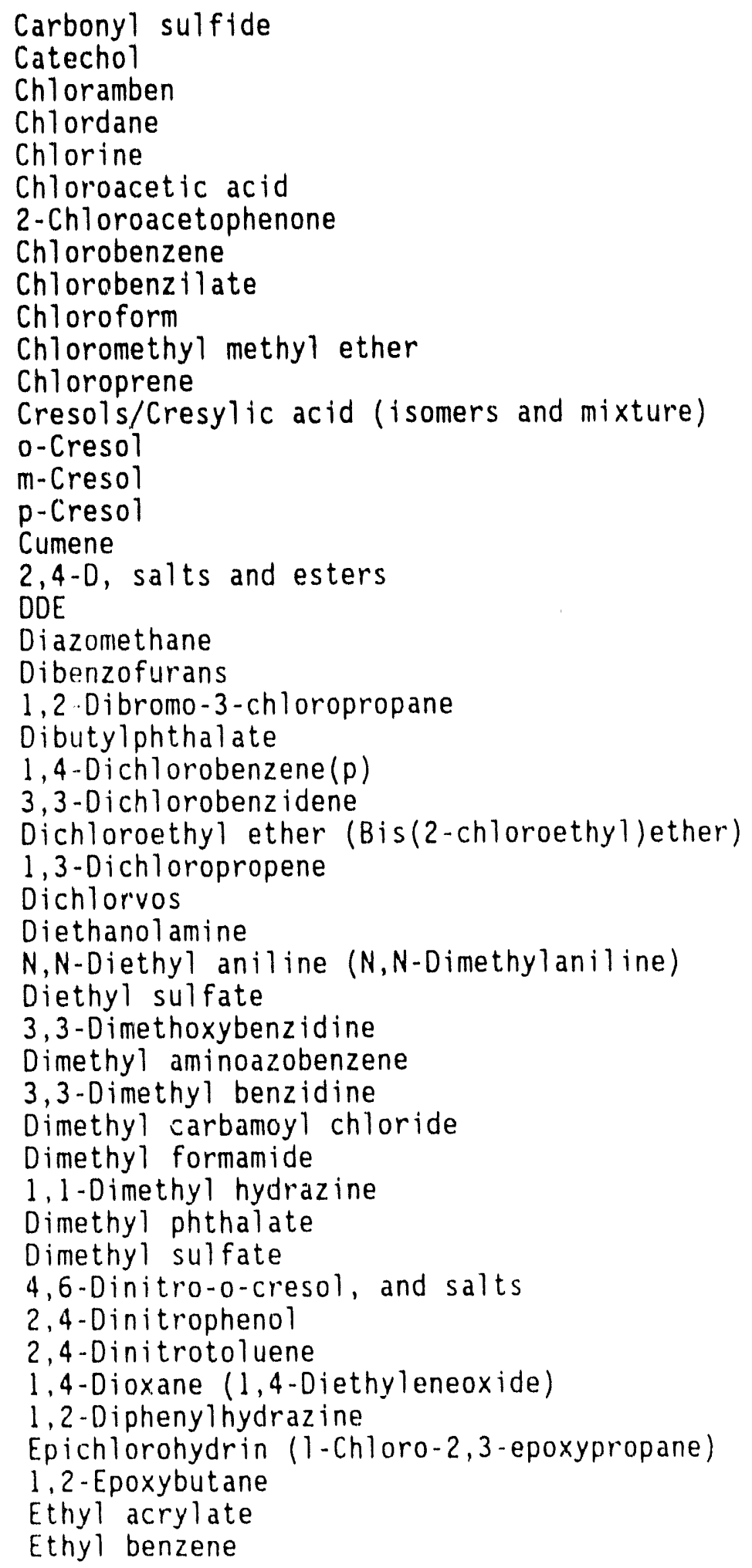

A. 2 
TABLE A.1, (contd)

Chemical name

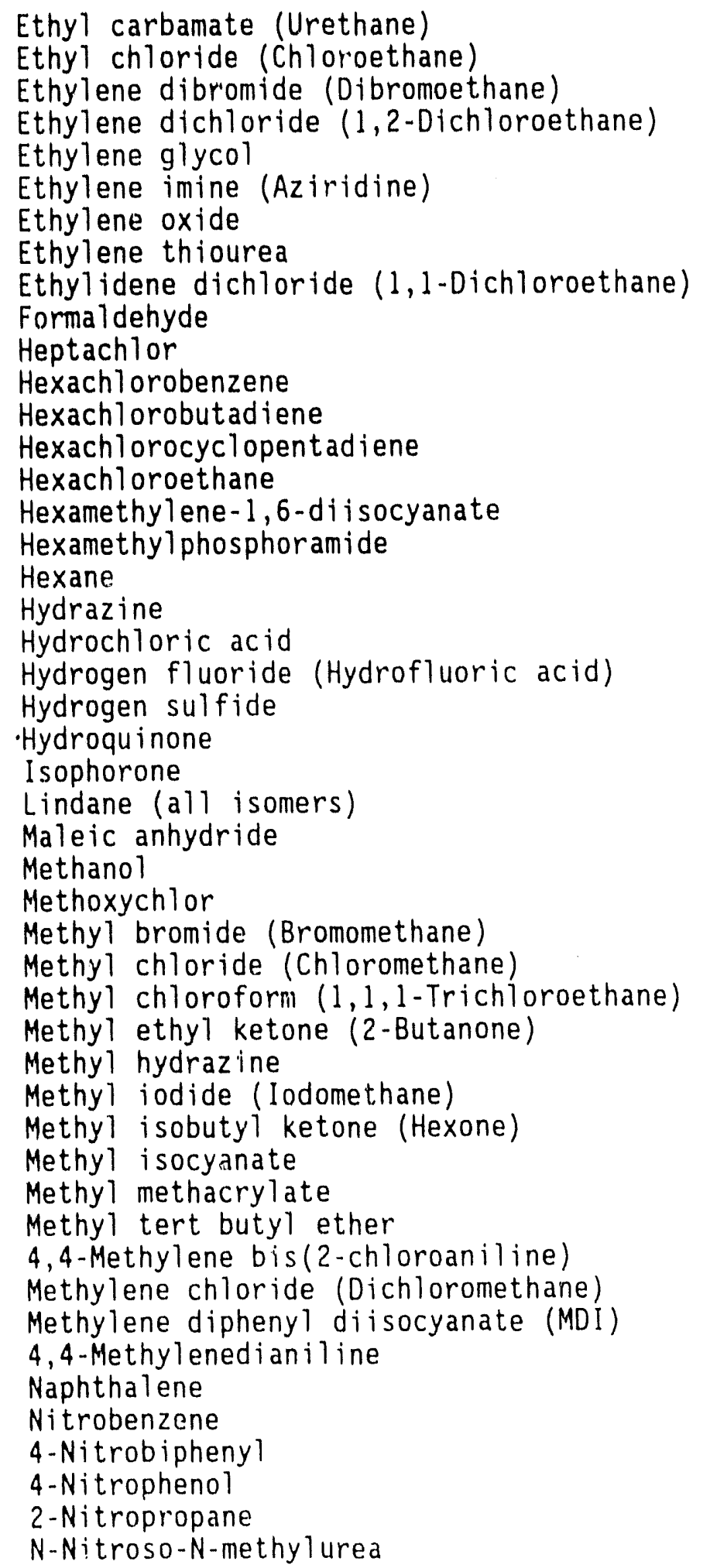


TABLE A.1. (contd)

Chemical name

$\mathrm{N}$-Nitrosodimethylamine

$\mathrm{N}$-Nitrosomorpholine

Parathion

Pentachloronitrobenzene (Quintobenzene)

Pentachlorophenol

Phenol

p-Phenylened tamine

Phosgene

Phosphine

Phosphorus

Phthalic anhydride

Polychlorinated biphenyls (Aroclors)

1,3-Propane sultone

beta-Propiol actone

Propionaldehyde

Propoxur (Baygon)

Propylene dichloride (1,2-Dichloropropane)

Propylene oxide

1,2-Propylenimine (2-Methyl aziridine)

Quinoline

Quinone

Styrene

Styrene oxide

$2,3,7,8$-Tetrachlorodibenzo-p-dioxin

$1,1,2,2$ - Tetrachloroethane

Tetrachloroethylene (Perchloroethylene)

Titanium tetrachloride

Toluene

2,4-Toluene diamine

2,4-Toluene diisocyanate

0 -Toluidine

Toxaphene (chlorinated camphene)

1,2,4-Trichlorobenzene

1,1,2-Trichloroethane

Trichloroethylene

2,4,5-Trichlorophenol

2, 4,6-Trichlorophenol

Triethylamine

Trifluralin

2,2,4-Trimethylpentane

Vinyl acetate

Vinyl bromide

Vinyl chloride

Vinylidene chloride (1,1-Dichloroethylene)

xylenes (isomers and mixture)

$0-x y l e n e s$

$m-x y l e n e s$

$p-x y l e n e s$ 
TABLE A.1. (contd)

Chemrical name

Ant imony Compounds

Arsenic Compounds (incrganic including arsine)

Bery 77 ium Compounds

Cadmiium Compound's

Chromilum Compounds

Cobalt Compounds

Coke Oven Emissions

Cyanide Compounds ${ }^{(a)}$

Glycol ethers $(b)$

Lead Compound's

Manganese Compounds

Mercury Compounds

Mineral fibers $(\mathrm{c})$

Nickel Compounds

Polycylic Organic Matter ${ }^{(d)}$

Radionuclides (including radon) ${ }^{(e)}$

Selenium Compounds

NOTE: For a 17 listings above that contain the word "compounds" and for g7ycol ethers, the following applies: Unless otherwise specified, these listings are defined as including any unique chemical substance that contains the named chemical (i.e., antimony, arsenic, etc.) as part of that chemical's infrastructure.

(a) $X^{\prime} C N$ where $X=H^{\prime}$ or any other group where a formal dissociation may occur. For example KCN or $\mathrm{Ca}(\mathrm{CN})$ ?

(b) Includes mono- and di-ethers of ethylene glycol, diethylene glycol, and triethylene glycol

$\mathrm{R}-(\mathrm{OCH} 2 \mathrm{CH} 2) \mathrm{n}-\mathrm{OR}$ ' where

$n=1,2$, or 3

$R=$ a 7 kyl or aryl groups

$R^{\prime}=R, H$, or groups which, when removed, yield glycol ethers with the structure: $\mathrm{R}-(\mathrm{OCH} 2 \mathrm{CH})_{n}-\mathrm{OH}$. Polymers are excluded from the glycol category.

(c) Includes glass microfibers, glass wool fibers, rock wool fiber's, and slag wool fibers, each characterized as "respirable" (fiber diameter less than 3.5 micrometers) and possessing an aspect ratio (fiber length divided by fiber diameter) greater than or equal to 3 , as emitted from uroduction of fiber and fiber products.

(d) Includes organic compounds with more than one benzene ring, which have a boiling point greater than or equal to $100^{\circ} \mathrm{C}$.

(e) A type of atom that spontaneously undergoes radioactive decay. 
APPENDIX B

TOP 5 TRI EMISSIONS FROM TOP GENERATING 4-DIGIT SICS 


\section{SIC 2611 (Pulp Mills)}

Methanol

ChToroform

Sulfuric Acid

Ammonium Sulfate

Hydrochioric Acid

\section{SIC 2621 (Paper Mills)}

Methanol:

Hydrochioric Acid

Chloroform

Sulfuric Acid

Acetone

SIC 2812 (Alkalies and Chilorine)

Hydrochloric Acid

Sulfuric Acid

Ethylene

Hexachloro-1-3-Butadiene

chlorine

SIC 2813 (Industrial Cases)

Hydrochloric Acid

Ammonia

Acetone

Methanol

Ammonium Sulfate

B. 1 
SIC 2816 (Inorganic Pigments)

Hydrochioric Acid

Ammonium Sulfate

Carbonyl Sulfide

Barium Compounds

Lead Compounds

SIC 2819 (Industrial Inorganic Chemicals, Not Elsewhere Classified)

Ammonium Sulfate

Sulfuric Acid

Hydrochloric Acid

Ammonia

Chromium Compounds

Acetonitrile

SIC 2821 (Plastics Materials, Synthetic Resins, and Nonvulcanizable

Elastomers)

Carbon Disulfide

Methanol

Ammonium Sulfate

Ethylene

Acetone

SIC 2822 (Synthetic Rubber :)

Ammonium Sulfate

Hydrochloric Acid

Toluene

Cyclohexane

Methanol

SIC 2823 (Cellulosic Manmade Fibers)

Carbon Disulfide

Acetone

B.2 
Zinc Compounds

Methyl Ethyl Ketone

Benzeme

$\underline{\text { SIC } 2833 \text { (Medicinal Chemicals and Botanical Products) }}$

Methanol

Dich Toromethane

Acetone

Toluene

Acetonitrite

SIC 2834 (Pharmaceutical Preparations)

Acetone

Dichloromethane

Methanol

Ammonium Sulfate

Toluene

SIC 2851 (Paints, Varnishes, Lacquers, Enamels, and Allied Products)

Xylene

Toluene

Methy 1 Ethyl Ketone

N-Butyl Alcohol

Methanol

SIC 2865 (Cyclic Organic Crudes and Intermediates, and Organic Dyes and

pigments)

Ammonia

Methanol

Ammonium Sulfate

Hydrochloric Acid

Sulfuric Acid 
SIC 2869 (Industrial Organic Chemicals, Not Elsewhere Classified)

\author{
Ammonium Sulfate \\ Methanol \\ Acetone \\ Hydrochloric Acid \\ Ethlylene Glycol
}

SIC 2873 (Nitrogenous Fertilizers)

Ammonia

Ammonium Sulfate

Ammonium Nitrate

Methanol

Acrylic Acid

SIC 2874 (Phosphatic Fertilizers)

Phosphoric Acid

Ammonia

Sulfuric Acid

Ammonium sulfate

Ammonium Nitrate

SIC 2911 (Petroleum Refining)

Ammonia

Toluene

xylene

Propylene

Aluminum Oxide

SIC 3079 (Misc. Plastic Products)

Acetone

Methanol

Methyl Ethyl Ketone 


\section{Dichloromethane}

Styrene

SIC 3312 (Steel Works, Blast Furnaces (including Coke Ovens), and Rolling

Mills)

Manganese Compounds

Zinc Compounds

Zine

Sulfuric Acid

Benzene

SIC 3321 (Gray and Doctile Iron Foundries)

Munganese

Zinc

$1,1,1-$ Trich Torethane

Zinc Compounds

Lead Compounds

SIC 3331 (Primary Smelting and Refining of Copper)

Copper Compounds

Zinc Compounds

Copper

Aluminum Oxide

Hydrochloric Acid

SIC 3339 (Primary Smelting and Refining of Nonferrous Metals, Except Copper and Aluminum)

Chlorine

Zine Compounds

Hydrochioric Acid

Lead Compounds

Ammoniuni Sulfate 
SIC 3341 (Secondary Smelting and Refining of Nonferrous Metals)

Aluminum Oxide

Aluminum

Lead

Sulfuric Acid

Ammonia

SIC 3711 (Motor Vehicles and Passenger Car Bodies)

Xylene

Glycol Ethers

Toluene

N-Butyl Alcohol

Methyl [sobutyl Ketone

SIC 3714 (Motor Vehicle Parts and Accessories)

Xylene

1,1,1-Trichloroethane

Toluene

Trichloroethylene

Methyl Ethyl Ketone 
APPENDIX C

IMTERVIEWS 


\title{
INTERVIEWS
}

\section{Trade Associations}

\author{
American Institute for Pollution Prevention \\ American Petroleum Institute \\ Chemical Manufacturers Association \\ Council on Solid Waste Solutions \\ Institute for Scrap Recycling \\ Motor Vehicles Manufacturers Association \\ National Association of Manufacturers \\ Petroleum Environmental Research Forum \\ Water Pollution Control Association
}

\section{Environmental Advocacy Groups}

Environmental Action Fund

Environmental Defense Fund

Greenpeace

Massachusetts Public Interest Research Group

National Toxics Campaign Foundation

National Wildlife Federation

Sierra Club

United States Public Interest Research Group

\section{Federal Agencies}

Bureau of Mines, Environmental Technology Division, California Air Resources Board Council on Competitiveness

EPA Hazardous Waste/Superfund Division

EPA Office of Environmental Engineering Technology

EPA Office of Research and Development

EPA Office of Toxic Substances 
EPA Pollution Prevention Office

EPA Risk Reduction Research Laboratory

EPA Safe Substitutes Project, Untversity of Tennessee

EPA Waste Minimization Research Branch

National Institutes for the Environment

Cffice of Technology Assessment

\section{Industrial Firms}

Allied Signal, Inc., Allied Fibers, Hopewe 11, VA

Boeing, Seattle, WA

Chevron Corporation, San Francisco, CA

Chevron Research and Development Corporation, Richmond, CA

Conoco, Inc., Ponca City, OK

Digital Equipment Corp., Boxboro, MA

DuPont, Antioch, CA

DuPont, Wilmington, DE

Evanite Fiber Corporation, Corvallis, OR

Exxon, Annandale, NJ

IBM, Washington, D.C.

Kimberly Clark, Neenah, WI

Occidental Chemical Corporation, Belle, WV

Polaroid Corporation, Cambridge, MA

PPG Industries, Inc., Pittsburgh, PA

Procter \& Gamble, Cincinatti, $\mathrm{OH}$

She11 Development Company, Houston, TX

Vulcan Chemicals, Wichita, KS

Weyerhaeuser, Tacoma, WA

W. R. Grace \& Company, Columbia, MD

$3 M$ Corporation, St. Paul, MN 


\section{DISTRIBUTION}

No. of

Copies

\section{OFFSITE}

12 DOE/Office of Scientific and Technical Information

R. Abarcar

Energetics, Inc.

7164 Gateway Drive

Columbia, MD 21046

Advanced Industrial Concepts Division

office of Industrial

Technologies

Forrestal Building/CE-232

1000 Independence Ave., S.W.

Washington, DC 20585

ATTN: D. J. Boron

M. E. Gunn, Jr.

C. Sorrell

Ehr-Ping Huang $\mathrm{Fu}$

B. Volint ine

O. K. Walter

K. P. Ananth

Battelle Columbus Laboratories

505 King Ave.

Columbus, $\mathrm{OH}$ 43201-26.93

P. Angelini

Martin Marietta Energy Systems, Inc.

Oak Ridge National Laboratory

P.0. Box 2009

Oak Ridge, TN 37831-8218
No. of

Copies

J. Atcheson

U.S. Environmental Protection Agency

401 M Street, S.W.

Washington, DC 20460

D. E. Blockste in

Committee for the National Institutes for the Environment

73011 th St. N.W.

Washington, DC 20001

B. L. Bush

American Petroleum Institute

$1220 \mathrm{~L}$. Street

Washington, DC 20005

H. L. Chum

National Renewable Energy Laboratory

1617 Cole Boulevard

Golden, CO 80401

J. Craig

Office of Policy, Planning, and Evaluation

Environmental Protection Agency

401 M. Street, SW

Washington, DC 20460 
No. of

Copies

H. B. Cranford, Jr.

Waste Material Management

Division

office of Industrial

Technologies

Forrestal Building/CE-222

1000 Independence Ave., S.W.

Washington, DC 20585

J. M. Davis

Assistant Secretary

Office of Conservation and

Renewable Energy

Forrestal Building

1000 Independence Ave, S.W.

Washington, DC 20585

G. DeMichele

Water Pollution Control

Federation

601 Wythe St.

Al exandria, VA 22314-1994

R. Dennison

Environmental Defense Fund

1616 P Street, NW

Washington, DC 20036

F. L. Dryer

Professor of Mechanical

Engineering and Aeronautical

Engineering

Princeton University

D316 Engineering Quadrangle

Princeton, NJ 08544-5263

J. J. Eberhardt

Office of Transportation Materials

Office of Transportation Technologies

Forrestal Building 1000 Independence Ave., S.W. Washington, DC 20585
No. of

Copies

G. Economos

National Materials Advisory Board

National Research Counci1

2101 Constitution Ave.

Washington, DC 20418

J. Eisenhauer

Energetics, Inc.

7164 Gateway Drive

Columbia, MD 21046

H. M. Freeman

U.S. Environmental Protection Agency

Risk Reduction Laboratory

$26 \mathrm{~W}$. Mart in Luther King Ave.

Cincinnati, $\mathrm{OH} 45268$

K. Friedman

Office of Industrial Techno?ogies

Forrestal Building/CE-20

1000 Independence Ave., S.W.

Washington, DC 20585

T. Hauser

American Institute for Pollution Prevention

Dept. of Civil and Environmental Engineering University of Cincinnati

730 Rhodes Hall (ML 71)

Cincinnati, $\mathrm{OH}$ 45221-0071

J. D. Idol, Jr.

PMMI Professor

Director, Center for Packaging

Science and Engineering

Titsworth and Bevier Road

Building 3529-Busch Carpus

Rutgers University

Piscataway, NJ 08855 
No. of

S.opies

G. R. Jasny

V.P. Technical Operations (Retired)

Martin Marietta Energy Systems

106 Dixie Lane

Oak Ridge, TN 37830

H. Klee, Jr.

Amoco Corporation

200 East Randolph Dr.

Chicago, IL 60601

A. W. Lindsey

Environmental Protection Agency

401 M. Street, SW

Washington, DC 20460

A. Maest

Environmental Defense Fund

1616 P Street, NW

Washington, DC 20036
A. Mason
Chemical Manufacturerș
Association
2501 M. Street, NW
Washington, DC 20037
W. J. McLean
Sandia National Laboratories
P.0. Box 969
Livermore, CA 94550
D. L. Morrison
Technical Director
Energy, Resources, and
Environmental systems
Division
MITRE Corporation
7525 Colshire Orive
Mclean, VA 22102

No, of

Copies

D. C. Nunenkamp

President

Total Energy Systems West, Inc.

1010 F Street - Suite 500

Sacramento, CA 95814

G. G. Ondich

Environmental Protection Agency

401 M. Street, SW

Washington, DC 20460

C. S. Padgett

Environmental Action 1525 New Hampshire Ave., NW Washington, DC 20036

G. Parshall

Director of Research

E.I. Dupont de Nemours \& Company

P.0. Box 80328

Experimental Station

Wilmington, DE 19880-0328

C. Pereira

W.R. Grace \& Company

Washington Research Center

7379 Route 332

Columbia, MD 21044

R. B. Pojasek

VP - Environmental Services

Geraghty \& Miller, Inc.

One Corporate Drive

Andover, MA 01810 
No. of

Copies

R. B. Rosenberg

Senior Vice President, Operations \& Industry Relations

Gas Research Institule

8600. West Bryn Mawr Avenue

Chicago, Il. 6063 I

L. Ross

Center for Waste Reduction Technolories

American institute of Chemical Engineers

345 E. 47th St.

New York, NY 10017

P. Ross

U.S. Environmental Protection Agency

401 M cot, S.W.

Washinguir, DC 20460

P. Roth

Energetics, Inc:

7164 Cateway Drive

Columbia, MD 21046

P. Salmon-Cox

Office of Industrial

Technologies

Forrestal Building/CE-23

1000 Independence Ave., S.W.

Washington, DC 20585

D. Sarrokin

U.S. Environmental Protection Agency

401 M Streset, S.W.

Washington, DC: 20460

L. B. Schililing

Improved Energy Productivity

Division

iffice of Industrial

Technologies

Forresta! Building/CE.231

1000 Independence Ave, S.W

washington, Do 20585
No. of

Copies

R. K. Sen

R. K. Sen \& Associates

3808 Veazey St. N.W.

Washington, DC 20016

P. Starke

Environmental Action

1525. New Hampshire Ave., NW

Washington, DC 20036

A. J. Streb

Office of Industrial

Technologies

Forrestal Building/CE-20

1000 Independence Ave., S.W. Washington, DC 20585

D. Swink

Office of Industrial

Technologies

Forrestal Building/CE-20

1000 Independence Ave., S.W.

Washington, DC 20585

J. W. Tester

Professor of chemical

Engineering

Director, Energy Laboratury

Room E40-455

Massachusetts Institute of Technology

Cambridge, MA 02139

A. Thomas

Argonne National Laboratory 9700 South Cass Ave.

Argonne, IL 60439.484]

D. E. Witey

Improved Energy Productivity Division

office of Industrial Technologies

Forrestal Building/CE-231

1000 Independence Ave., S.W Washington, D: 20585 
No. of

Copies

T. Willitams

Water Pollution Control

Federation:

601 Wythe 5t.

Alexandria, VA 22314-1994

FOREIGN

K. 07denburg

UN Environmental Program Industry and Environment office

Tour Mirabeau 39-43, QUAI

Andre Citron

75739 Paris CEDX 15

\section{ONSITE}

DOE Richland Field office

R. B. Goranson

57 Pacific Northwest Laboratory

R. C. Adamis

W. B. Ashton

E. G. Baker

R. S. Butney
No. of

Copies

D. E. Deonigi

J. A. Dirks

K. K. Daellenbach

R. E. Einziger

L. L. Fassbender (15)

C. A. Geffen

B. A. Garrett

M. G. Hefty

C. H. Imhoff

B. R. Kinzey

T. L. Kuusinen

G. L. McVay

R. K. Quinn

D. A. Seaver.

L. J. Silva

J. L. Straalisund

J. L. Sealock

S. A. Weakley

J. K. Young (15)

Publishing Coordination

Technical Report Files (5) 


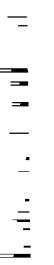

